NBER WORKING PAPER SERIES

\title{
FISCAL DEFICITS AND RELATIVE PRICES IN A GROWING WORLD ECONOMY
}

\author{
Maurice Obstfeld
}

Working Paper No. 2725

\author{
NATIONAL BUREAU OF ECONOMIC RESEARCH \\ 1050 Massachusetts Avenue \\ Cambridge, MA 02138 \\ October 1988
}

I am grateful for comments from Peter Neary, Bruce Smith, and Philippe Weil; from participants in the Rochester-Western Ontario Conference on exchangerate volatility; and from seminar participants at the NBER 1987 Summer Institute, Columbia University, Johns Hopkins University, the Bank of Finland, and the Federal Reserve Board's International Finance Division. All errors are my responsibility. Financial support from the National Science Foundation, the NBER 01in visiting scholar program, and the Alfred P. Sloan Foundation is acknowledged with thanks. This research is part of NBER's research program in International Studies. Any opinions expressed are those of the author not those of the National Bureau of Economic Research. 
NBER Working Paper \#2725

October 1988

FISCAL DEFICITS AND RELATIVE PRICES IN A GROWING WORLD ECONOMY

\section{ABSTRACT}

This paper studies the transmission of fiscal disturbances between countries, and the effect of those disturbances on worldwide capital intensity, in a context of growth. The model developed to address these issues allows for the production of both nontradable and relatively capital-intensive tradable goods; a central finding is that factor markets can be a major channel for the communication of fiscal policy shocks to world interest rates, to private saving decisions, and, ultimately, to global asset supplies and their distribution among countries.

Particular predictions of the model illustrate how changes in public debt ratios and shifts in government spending patterns affect resource allocation and welfare. For example, an increase in a small country's per capita public debt leads to long-run crowding-in of capital and the impoverishment of future generations; a similar policy shift by a large country crowds out capital on a global scale, impoverishes future domestic generations, and has ambiguous effects abroad. 


\section{Introduction}

This paper studies the longer-term dynamic effects of national fiscal policies in a context of economic growth. Particular attention is given to the transmission of fiscal disturbances between countries and to the effect of those disturbances on worldwide capital intensity. The model employed allows for the production of both nontradable and relatively capitalintensive tradable goods. A central finding of the analysis is that factor markets can be a major channel for the transmission of fiscal policy shocks to interest rates, to private saving decisions, and, ultimately, to global asset supplies and their distribution among countries. 1

The framework underlying the model is one in which the Ricardo-Barro equivalence of public debt issue and taxation [see Barro (1974)] does not hold. Nonequivalence arises from a factor first examined by Weil (1985): economic growth is fueled by the birth of new households that are unconnected with the existing households that hold the public debt. Because current debt holders do not value the consumption of unborn taxpayers, a fraction of the public debt proportional to the growth rate of the population represents net wealth to existing households.

A number of authors have examined international aspects of fiscal policies in models where agents' intertemporal objectives and constraints are explicitly modelled. The present effort is complementary and explores questions of fiscal policy from a somewhat different perspective. Frenkel and Razin (1986a) develop a global version of Blanchard's (1985) uncertainlifetime setup in which the labor force and supplies of tradable and nontradable goods are fixed. Giovannini (1988) and Buiter (1986) use similar models and incorporate capital accumulation; but neither Giovannini's comparative steady-state analysis nor Buiter's simulation methodology provides an analytical characterization of the world economy's 
dynamics. Greenwood and Kimbrough (1985) focus on cross-border fiscal transmission in the presence of capital controls.

The study that comes closest to the present one is by Persson (1985), who uses Buiter's (1981) open-economy extension of Diamond's (1965) lifecycle growth model to conduct a careful welfare analysis of debt policies in a global setting. The dynamic methods used in the present paper differ significantly from Persson's, however, and lead to a useful alternative perspective from which to analyze certain disturbances. In addition, the Buiter-Persson assumption of a single good abstracts from demand-side effects on interest rates that play a key role below. Fried and Howitt (1988) examine a model similar to Persson's, but with capital in fixed supply.

Some main results of my analysis illustrate the important role of factor markets in a world economy producing nontradables as well as tradables:

1. Long-run crowding in. In the long run, a small economy that increases its steady-state ratio of real public debt to population suffers a fall in per capita expenditure but a $\underline{\text { rise }}$ in its per capita capital stock. External debt rises, however, by more than the increase in capital. Under the above-mentioned assumption that tradables are the capitalintensive good, the increase in capital per worker is inevitable if the economy's production of tradables is to cover its increased debt-servicing requirements.

2. Global crowding out. The preceding result may be reversed when debt expansion is undertaken by a large country capable of affecting the world interest rate. The reason is that a rise in any country's long-run public-debt ratio crowds out capital globally. 
3. Government purchases of tradables and nontradables. Government purchases of nontradables are likely to result ultimately in a lower world capital stock and lower average world consumption than equivalent purchases of tradables.

The paper is organized as follows. Section 2 describes a smallcountry model and section 3 uses that model to analyze unanticipated and anticipated fiscal policy moves. This partial-equilibrium model is useful for developing the intuition behind the general-equilibrium global model set out in section 4 . Section 5 studies the consequences of various fiscal policies in a global setting. Section 6 discusses possible extensions of the paper's analysis.

2. Model structure: Consumption and production

This section describes a small open economy with a growing population of infinitely-lived households. Population and labor force are, by assumption, the same. The economy's firms combine capital and labor to produce both internationally traded goods and nontraded goods. Although the economy's labor supply is given at any point in time (there is no cross-border labor migration), capital is internationally mobile [as in Mundell (1957)]. The domestic capital stock therefore can be augmented instantaneously and without adjustment cost by external borrowing.

A. Households

At time $t$, a household that came into existence on date $v \leq t$ (its vintage) maximizes

$$
U(v, t)-\int_{t}^{\infty} u\left[c^{T}(v, s), c^{N}(v, s)\right] \exp [-\delta(s-t)] d s .
$$


where $\delta>0$ is the subjective time-preference rate, $c^{T}\left(c^{N}\right)$ is consumption of traded (nontraded) goods, and

$$
u\left(c^{T}, c^{N}\right)=\left[\left(c^{T}\right)^{\nu}\left(c^{N}\right)^{1-\nu}\right]^{1-R} /(1-R) \quad(R>0) .
$$

Since the small economy will later be embedded in a trading world economy, it is natural to choose traded goods as the numeraire for measuring asset stocks and factor rewards. Total household consumption expenditure, measured in terms of traded goods, is denoted $c(v, t)$. If $q(t)$ is the price of traded goods in terms of nontraded goods,

$$
c(v, t) \equiv c^{T}(v, t)+c^{N}(v, t) / q(t) .
$$

The household holds financial assets $a(v, t)$, supplies its unt labor endowment inelastically at the wage rate $w(t)$, and, at each moment $t$, receives net transfers $r(t)$ from the government. The assumption that these lump-sum transfers are not vintage-specific is reflected in the notation, and is crucial in generating the non-Ricardian debt effects studied below. If $r(t)$ is the interest rate in terms of traded goods, the household intertemporal budget constraint is

$$
\begin{aligned}
& \int_{t}^{\infty} c(v, s) \exp \left[-\int_{t}^{s} r(z) d z\right] d s \\
& \quad \leq a(v, t)+\int_{t}^{\infty}[w(s)+r(s)] \exp \left[-\int_{t}^{s} r(z) d z\right] d s .
\end{aligned}
$$

Let $h(t)$ denote household human wealth, 


$$
h(t)=\int_{t}^{\infty}[w(s)+r(s)] \exp \left[-\int_{t}^{s} r(z) d z\right] d s
$$

which is assumed to be positive at each moment. Then the spending plan that maximizes lifetime welfare $U(v, t)$ subject to (1) (assuming existence) is

$$
c(v, t)=\Omega(t)[a(v, t)+h(t)] .
$$

where

$$
1 / \Omega(t) \equiv \int_{t}^{\infty} \exp \left\{\int_{t}^{s}[r(z)+(1-\nu) \hat{q}(z)] d z\right)(1-R) / R \exp [-\delta(s-t) / R] d s
$$

and $\wedge$ denotes a percentage change. In the $\log$ case $(R=1), \Omega(t)=\delta$.

Expenditure is divided between the two consumption goods according to the rule

$$
c^{T}(v, t)=v c(v, t), c^{N}(v, t)=(1-\nu) q(t) c(v, t) .
$$

The expenditure shares given by (5) yield the following interpretation of the consumption function defined by (3) and (4). Consumption spending is a proportion of total (nonhuman plus human) wealth that depends on the expected future path of the real interest rate $r(t)+(1-\nu) \hat{q}(t)$, that is, the rate of interest in terms of the domestic consumption basket [see Obstfeld (1985)]. The effect of this real interest rate on spending depends on whether $R<1$ (so that substitution effects dominate) or $R>1$ (so that income effects dominate). 
B. Relative prices

Traded and nontraded goods are produced with capital and labor under neoclassical conditions, including constant returns to scale.

Nonspecialization in production is assumed. Production technologies are described by the per capita production functions $F^{T}\left(k^{T}, n^{T}\right)$ and $F^{N}\left(k^{N}, n^{N}\right)$, where $\mathrm{k}^{\mathrm{T}}\left(\mathrm{k}^{\mathrm{N}}\right)$ is the amount of capital, per unit labor force, employed in producing traded (nontraded) goods, and $n^{T}\left(n^{N}\right)$ is the corresponding per capita labor Input. Because the above outputs and Inputs are divided by the economy's total labor force, $n^{T}+n^{N}=1$.

One unit of the traded good can be transformed into one unit of installed capital with no time lag. Thus, in a small economy for which the interest rate in terms of traded goods is given, a unique domestic wage is determined by the zero-profit condition in tradables production.

At a world interest rate of $r$, the optimal capital-labor ratio in the traded sector, $x^{T}(r)$, is found by equalizing the marginal product of capital and the interest rate,

$$
\mathrm{F}_{\mathbf{k}}^{\mathrm{T}}\left[\mathbf{x}^{\mathrm{T}}(\mathrm{r}), 1\right]=\mathrm{r}
$$

(so that $x^{T}(r)=1 / F_{k k}^{T}\left[x^{T}(r)\right]<0$ ). The domestic wage in terms of tradables, w, must then lie on the factor-price frontier,

$$
w=w(r)=F^{T}\left[x^{T}(r), 1\right]-r x^{T}(r) .
$$

This locus has a negative slope equal to $-x^{T}(r)$.

The capital-labor ratio in nontradables, $x^{N}(q r)$, is the solution to 


$$
F_{k}^{N}\left[x^{N}(q r), 1\right]=q r
$$

Since $r$ determines the wage $w$, however, the usual Stolper-Samuelson reasoning implies that $q$ can be written as a function of $r$ alone,

$$
q=q(r) \text {. }
$$

(In a sense, factor mobility is a substitute for commodity trade in this model, because countries that are nonspecialized in the same outputs, and that have the same production functions, will have the same relative price of nontraded goods if they face a common world interest rate.) The direction of influence of $r$ on $q$ depends on sectoral factor intensities. The most natural assumption, an important one for the analysis to follow, is that nontradables are relatively labor intensive. This factor-intensity assumption implies that a rise in $r$ (which lowers the wage measured in traded goods) causes the relative price of tradables, $q$, to rise:

$$
q^{\prime}(r)>0
$$

The capital-labor ratio in nontradables, $x^{N}[q(r) r]$, is a decreasing function of $r .^{2}$

\section{Factor supplies and production}

The number of households $H(t)$ in the economy grows at rate $\mu>0$, so that if $H(0)$ is taken to be $1, H(t)=\exp (\mu t)$. The implied labor supply of $H(t)$, together with consumer demand, determines the level of the capital stock and the allocation of factors between sectors. 
Equation (5) shows that household v's demand for nontradables is $c^{N}(v, t)=(1-\nu) q(t) c(v, t)$. Aggregate per capita consumption spending in the economy is defined by

$$
c(t)=\left[c(0, t)+\mu \int_{0}^{t} \exp (\mu v) c(v, t) d v\right] / H(t),
$$

which is assumed to be positive for all $t$. Thus, the per capita demand for nontradables is $c^{N}(t)=(1-\nu) q(t) c(t)$.

Figure 1 illustrates the economy's production side. Let $g^{N}$ be per capita government demand for nontradables. The market for nontraded goods clears when per capita supply equals per capita demand, that is, when

$$
(1-\nu) q(r) c+g^{N}=n^{N} \cdot F^{N}\left(x^{N}[q(r) r], 1\right) .
$$

The NN schedule in the figure shows combinations of $r$ and $n^{N}$ such that the nontraded-goods market clears for given values of aggregate per capita consumption $c$ and government demand $g^{N}$. Because a rise in $r$ both raises the demand for nontradables (by raising $q$ ) and lowers the capital-labor ratio in production, employment in nontradables must expand as $r$ rises to maintain equilibrium. The NN schedule therefore has the positive slope shown,

The KK schedule in the lower panel of figure 1 shows how the economy's capital stock is determined. The per capita supply of capital, $k$, is

$$
k=\left(1-n^{N}\right) x^{T}(r)+n^{N} x^{N}[q(r) r]
$$




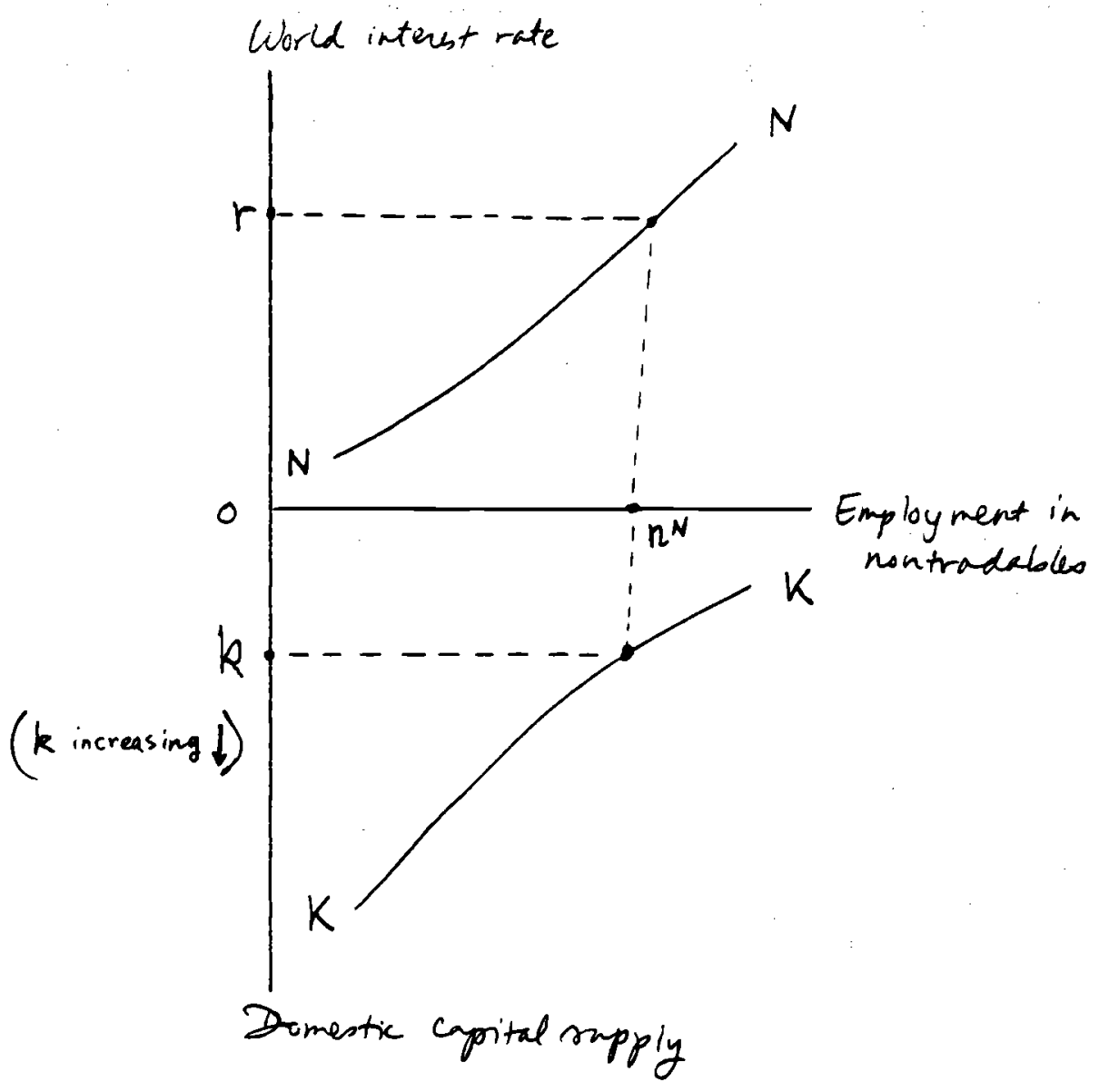

Figme 1 
KK's slope in flgure 1 reflects the assumption that nontraded goods are relatively labor intensive. (A movement downward from the origin is a rise in k.) Notice that a rise in the interest rate, by reducing capital-1abor ratios in both sectors, shifts $\mathrm{KK}$ upward.

\section{Equilibrium: Deficits and dynamics}

The economy's dynamic equilibrium can be described by a pair of differential equations that govern the evolutions of aggregate consumption and the economy's outside asset holdings. To derive these equations, however, it is first necessary to examine the behavior of the domestic government.

\section{A. Government spending and finance}

An infinftely-lived government consumes both types of good, financing its purchases by levying taxes and issuing debt. If $\mathrm{d}$ denotes the government's per capita debt (measured in tradables) and $\mathrm{g}^{\mathrm{T}}$ its per capita consumption of tradables, then government debt follows the equation

$$
\dot{d}(t)=[r(t)-\mu] d(t)+g^{T}(t)+g^{N}(t) / q(t)+r(t) .
$$

Assume that for all $t, r(t)>\mu$; this condition rules out dynamic inefficiency in a world economy growing at rate $\mu$. Then the assumption

$$
\lim _{s \rightarrow \infty} \exp \left\{-\int_{t}^{s}[r(z)-\mu] d z\right\} d(s)=0
$$

confines the government within its intertemporal budget constraint; that is, (13) restricts the present discounted value of purchases plus net 
transfers to be no greater than initial public-sector assets. Evidence presented by Abel et al. (1986) supports a stochastic analogue of the dynamic efficiency assumption for the United States economy post-1929.

B. Private asset accumulation

The household budget constraint (1) implies the law of motion for household financial assets

$$
\dot{a}(v, t)=r(t) a(v, t)+w(t)+r(t)-c(v, t) \text {. }
$$

The implied law of motion for aggregate per capita assets, a(t), is

$$
\dot{a}(t)=[r(t)-\mu] a(t)+w(t)+\tau(t)-c(t) .
$$

Equation (14) follows from the assumption that newly-born households are not altruistically linked to existing ones, so that financial assets at birth, $a(t, t)$, are always zero.

The law of motion for $c(t)$ follows from definition (9) and from the behavior of individual households. Each individual household in cohort $v$ arranges for its total consumption spending $c(v, t)$ to rise at the rate

$$
\frac{\dot{c}(v, t)}{c(v, t)}=\frac{r(t)-\delta}{R}+\frac{(1-R)(1-\nu)}{R} \hat{q}(t) \equiv \eta(t) .
$$

[see equations (3) and (4)]. Differentiation of (9) therefore leads to

$$
\dot{c}(t)=\eta(t) c(t)+\mu[c(t, t)-c(t)] .
$$


The time derivative of per capita consumption is explained by the two term on the right-hand side above. The first term results from the fact that the consumption of all preexisting households rises at rate $\eta(t)$. The second term arises because the consumption of new households, which are born without financial wealth, differs from the economy-wide average. Since average consumption is easily calculated [from (3) and (9)] to be $\Omega(t)[a(t)+h(t)]$, while the consumption of a new household is $\Omega(t) h(t)$, per capita consumption evolves according to

$$
\dot{c}(t)=\eta(t) c(t)-\mu \Omega(t) a(t) .
$$

If the economy consisted of a single dynasty that equalized the consumption of all its constituent households, "marginal" and "average" consumption would be the same and the latter would therefore grow at rate $\eta(t)$, as in the standard optimal growth literature [for example, Koopmans (1967)]. Because the newborn are endowed at birth only with human wealth, however, the present model implies different dynamics and, as pointed out by Weil (1985), the possibility that Ricardo-Barro equivalence breaks down

\section{Aggregate dynamics}

To simplify notation, I assume that the stocks of government debt and capital are owned entirely by domestic residents. (Agents could always borrow abroad to bring about this portfolio allocation without disturbing equilibrium.) Remaining national wealth consists of net claims on foreigners, with a per capita level denoted by $f(t)$. Asset stock a(t) thus equals $k(t)+f(t)+d(t)$, so that equation (16) becomes 


$$
\dot{c}(t)=\eta(t) c(t)-\mu \Omega(t)[k(t)+f(t)]-\mu \Omega(t) d(t)
$$

When combined, the government finance constraint (12) and the private finance constraint (14) imply

$$
\begin{aligned}
\dot{k}(t)+\dot{f}(t)= & {[r(t)-\mu][k(t)+f(t)]+w(t)-c(t)-g^{T}(t) } \\
& -g^{N}(t) / q(t) .
\end{aligned}
$$

Equations (17) and (18) determine the evolution of average consumption and the economy's average "outside" assets, $k(t)+f(t)$. Notice that while the latter sum is predetermined, its two components are not: it is always possible, for example, to borrow a discrete lump of tradables abroad and install it instantly as capital. That is why (11) always holds even though $r$ is fixed. Equation (18) limits the economy's accumulation of new outside assets, however, to its overall net saving.

Under the simplifying assumption that the world interest rate is constant at level $r, q=q(r)$ and $w-w(r)$ are also constant; thus, $\Omega(t)=$ $r+(\delta-r) / R$, and $\eta(t)-(r-\delta) / R$. (The condition $\Omega>0$, which is necessary for the existence of an individual optimum, is assumed.) The sign of $\eta$ determines, by (17), whether the private sector has a positive or negative average financial-asset level in steady state.

Equations (17) and (18) now reduce to a system of nonautonomous equations with constant coefficients. Which solution for this system is the economically relevant one? To answer this question, note that equation (12) implies 


$$
\int_{t}^{\infty} \tau(s) \exp [-r(s-t)] d s=-d(t)+\int_{t}^{\infty}[\mu d(s)-g(s)] \exp [-r(s-t)] d s .
$$

where $g(t)$ is total per capita government consumption measured in traded goods. ${ }^{3}$ Expression (19) can be used to compute per capita human wealth and thus per capita consumption $c(t)$, which is given by

$$
\begin{aligned}
c(t)= & \left(r+\frac{\delta-r}{R}\right)\left(k(t)+f(t)+\frac{w(r)}{r}\right. \\
& \left.+\int_{t}^{\infty}[\mu d(s)-g(s)] \exp [-r(s-t)] d s\right] .
\end{aligned}
$$

It can be verified, however, that (20) is the consumption level implfed by the saddlepath solution to (17) and (18) when the two roots of that system, $r$ and $-\mu+(r-\delta) / R$, are, respectively, positive and negative. If consumption $c(t)$ and human wealth $h(t)$ are positive in a steady state, however, $-\mu+(r-\delta) / R<0$, and saddlepath stability is therefore assured. 4 Positive human wealth clearly requires also that government spending not be "too large" relative to the aggregate wage bill.

Equation (20) shows that consumption responds positively to current and prospective increases in the per capita national debt, with a responsiveness that disappears as the growth rate $\mu \rightarrow 0$. Accordingly, increased deficits stimulate private consumption, other things (in particular government consumption) equal. Equation (19) shows the reason for this failure of Ricardo-Barro equivalence. The current per capita public debt $d(t)$ contributes an equal negative con anent to each living individual's expected future transfers. However, this future tax burden is partially offset by the fact that some of the taxes will be levied on other 
households that are not yet alive. ${ }^{5}$ clearly debt issue, other things equal, benefits existing generations at the expense of future generations.

D. A digression on the Barro-Feldstein exchange

A good illustration of the effect operating in (20) comes from reconsidering the exchange between Barro (1976) and Feldstein (1976) over the Ricardian equivalence proposition of Barro (1974). Feldstein argued that in a dynamically efficient economy growing at a positive rate $\mu$, part of the government's interest bill can be financed by issuing the new debt needed to maintain a constant per capita debt level. Barro countered by showing that even under this financing scheme, the present value of future taxes on an initial debt issue of $D(0)$ is still

$$
\int_{0}^{\infty}(r-\mu) D(s) \exp (-r s) d s=(r-\mu) D(0) \int_{0}^{\infty} \exp [-(r-\mu) s] d s=D(0) .
$$

and not $(r-\mu) D(0) / r$, the value suggested by Feldstein. In essence, the present value of the new debt issued at rate $\mu$ is offset by the present value of the implied additional interest payments. Barro concluded (1976, p. 344) that "the presence of growth in the economy (at a rate below $r$ ) leaves unchanged the conclusion that government bonds are not net wealth." While Barro's conclusion that government bonds are not net wealth holds in his own model, it need not hold in the present economy, where households do not internalize taxes levied on unborn households. When future taxes are to be spread among a larger set of unconnected households, each existing household computes its own discounted tax bill under Feldstein's scheme as the product of $\exp (-\mu t)$ (the reciprocal of population) and 


$$
\begin{aligned}
\int_{0}^{\infty}(r-\mu) D(s) \exp (-\mu s) \exp (-r s) d s & =D(0)-\mu \int_{0}^{\infty} D(0) \exp (-r s) d s \\
& =(r-\mu) D(0) / r .
\end{aligned}
$$

Thus, a fraction $\mu / r$ of the initial per capita debt $d(0)$ is per capita net wealth. This expression, however, is the same as the one implied by (19) for the case of a constant per capita debt. The present value of the taxes that service $D(0)$ is of course $D(0)$ (as Barro observed), but the fraction of these taxes to be paid by households alive at time 0 is only $(r-\mu) / r^{6}$

\section{E. Diagrammatic analysis}

Under further assumptions that $d(t)$ and $g(t)$ are constant at levels $d_{0}$ and $g_{0}$, the dynamics implied by equations (17) and (18) can be summarized in a useful diagram (see figures $2 a$ and $2 b$ ). The steady-state per capita levels of consumption and outside assets, $c_{0}$ and $(k+f)_{0}$, are given by

$$
c_{0}=\frac{\mu[(1-R) r-\delta]\left[w(r)-g_{0}-(r-\mu) d_{0}\right]}{\operatorname{Rr}[-\mu+(r-\delta) / R]},
$$

$$
(k+f)_{0}=\frac{(\delta-r)\left[w(r)-g_{0}\right]-\mu[(1-R) r-\delta] d_{0}}{\operatorname{Rr}[-\mu+(r-\delta) / R]} .
$$

The two configurations shown represent the cases $r<\delta$ (figure 2a) and $r>\delta$ (figure $2 b$ ). When $r-\delta$, consumption is stationary along a vertical locus. The previous results imply that the economy travels to the steady state along the saddlepath SS. 


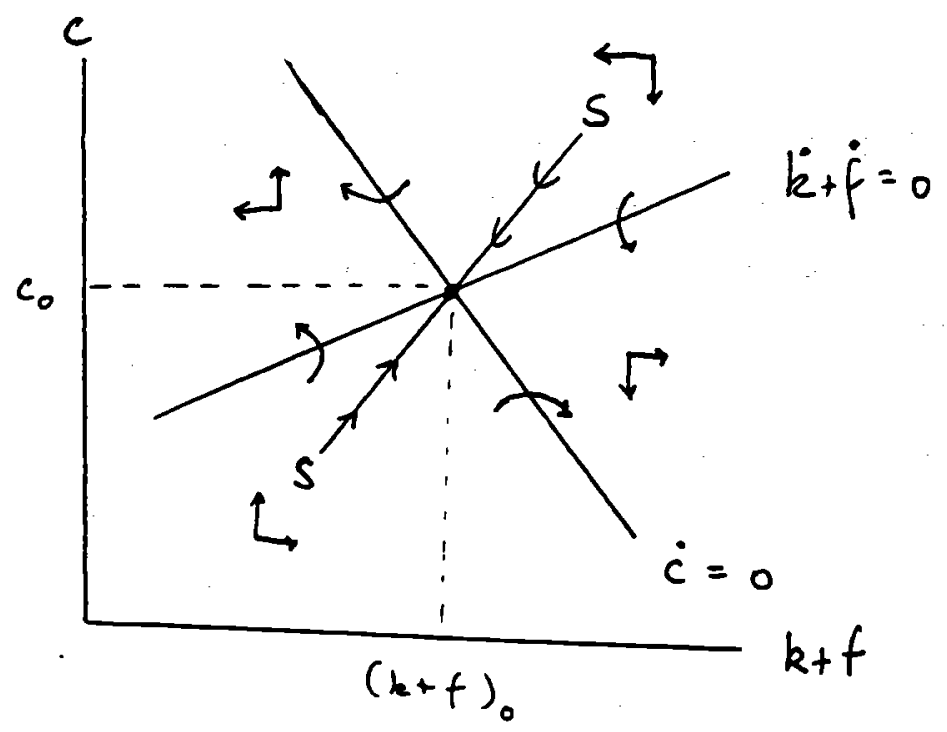

Figme $2 a \quad(r<\delta)$

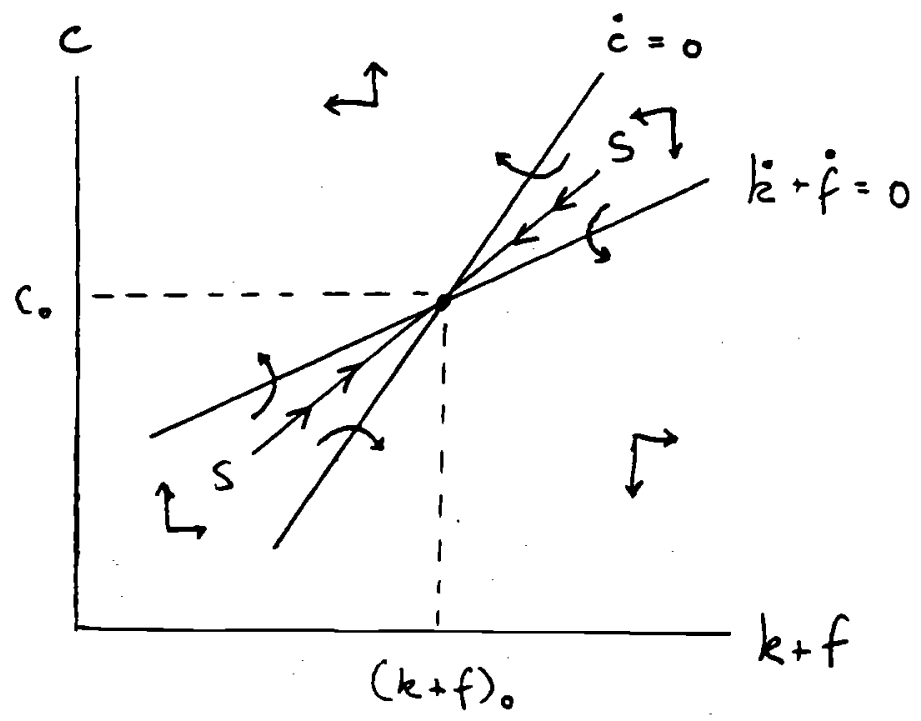

Figme $2 b \quad(r>\delta)$ 
4. Fiscal policies in a small open economy

The framework developed so far can be used to analyze a variety of fiscal policies. Below, the diagram introduced in the last section is applied to changes in the per capita public debt and in government purchases.

A. Current and anticipated changes in public debt

Equation (19) offers a full account of how changes in the per capita public debt affect consumption. The main intuition can be derived, however, from using figures $2 a$ and $2 b$ to analyze one-time changes in $a$ constant per capita debt level.

Consider, for example, a permanent unanticipated rise in debt per capita, from $d_{0}$ to $d_{1}$. This change should be visualized as a gift $\Delta d=d_{1}$ - $d_{0}$ of government bonds to the public [as in Barro (1974)], accompanied by a permanent rise $(r-\mu) \Delta d / r$ in the present value of each household's tax bill. The fiscal policy is associated with a permanent increase in the government budget deficit because the flow of new debt must rise to keep per capita debt at a higher level.

Equations (20) and (2I) show that the policy shift lowers the steadystate value of per capita consumption (to $c_{1}$ ) and lowers long-run outside assets [to $\left.(k+f)_{1}\right] \cdot{ }^{7}$ Since the qualitative affects of the adjustment do not depend on the sign of $r-\delta$, only the case $r>\delta$ is illustrated (in figure 3).

Consumption rises sharply (and saving thus falls) as the economy jumps from its intial equilibrium at point $A$ to point $B$ on the new saddlepath. The issue of a new debt thus has an initially expansionary impact. Consumption falls and outside assets are run down, however, as the economy 


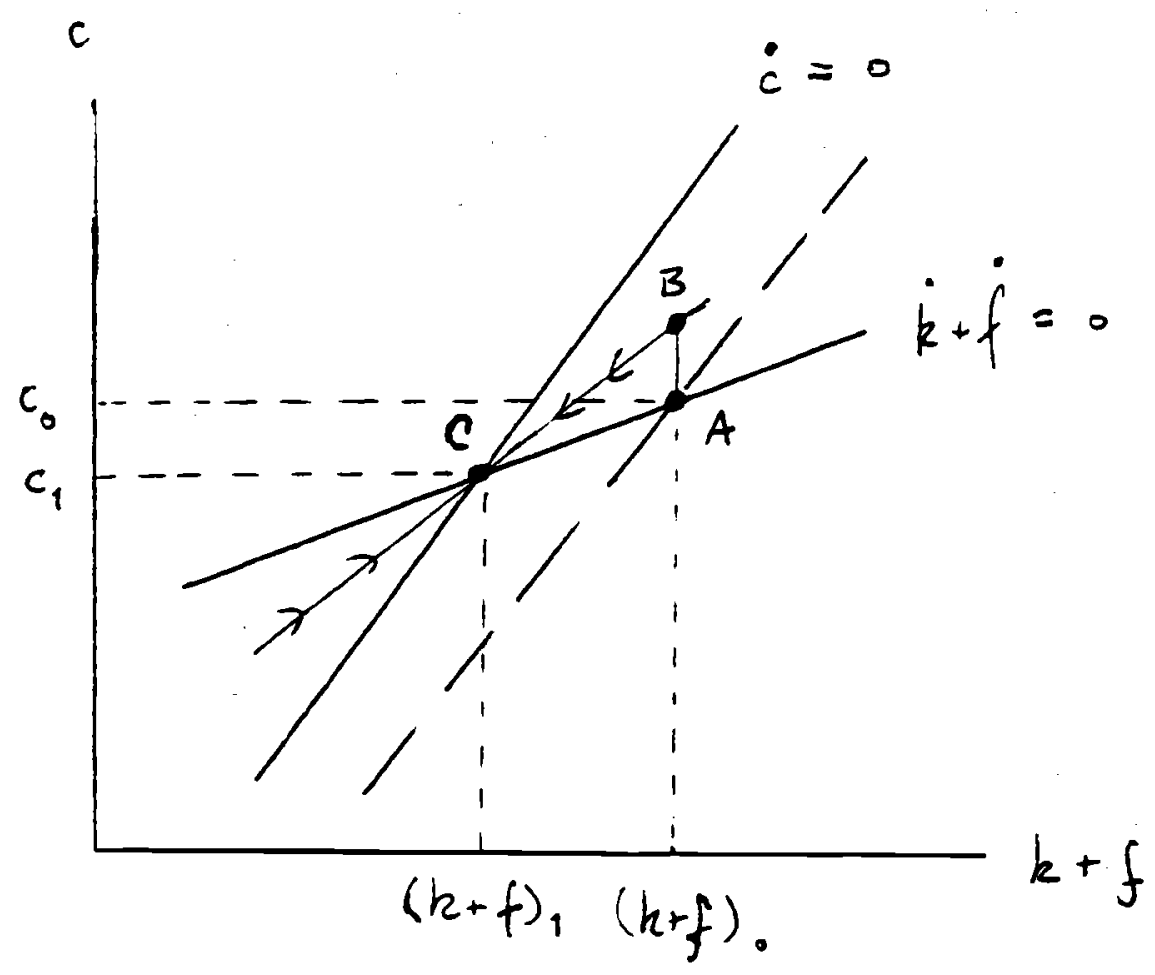

Figre 3 
moves to its new long-run equilibrium (point $C$ ). Ultimately, the debt expansion crowds out productive assets and the economy's long-run consumption per household is correspondingly lower.

Figure 4 illustrates the implications of this adjustment process for the product and factor markets. The rise in private consumption initially shifts the NN schedule rightward, increasing employment in nontradables from $n_{A}^{N}$ to $n_{B}^{N}$. At given relative output prices, the resulting expansion in nontradables can occur only if capital leaves the economy (the Rybczynski effect). There is therefore an instantaneous fall in the capital stock (from $k_{A}$ to $k_{B}$ ) as machines are dismantled and sold for foreign assets. Since the fall in capital also reduces output of tradables, the economy, after its initial acquisition of foreign assets, has a current account deficit.

These effects are reversed in the long run as consumption falls below its starting level. Employment in nontradables drops to $\mathrm{n}_{\mathrm{C}}^{\mathrm{N}}$ and the capital stock therefore rises to $\mathrm{k}_{\mathrm{C}}$. Because the economy's overall outside assets end up being lower, however, the economy must experience a cumulative current-account deficit in the transition from point $A$ to point $C$. Surprisingly, the debt expansion crowds in capital in the long run. This additional capital is, however, working for foreigners: the economy must have a higher capital-labor ratio in the long run if it is to produce enough tradables to service its higher per capita foreign debt. Notice also that the economy's current-account deficit is higher in the new steady state.

An anticipated future increase in the per capita public debt is analyzed in figure 5. When the future policy is announced, there is an immediate upward jump in consumption (from point A to point B). 


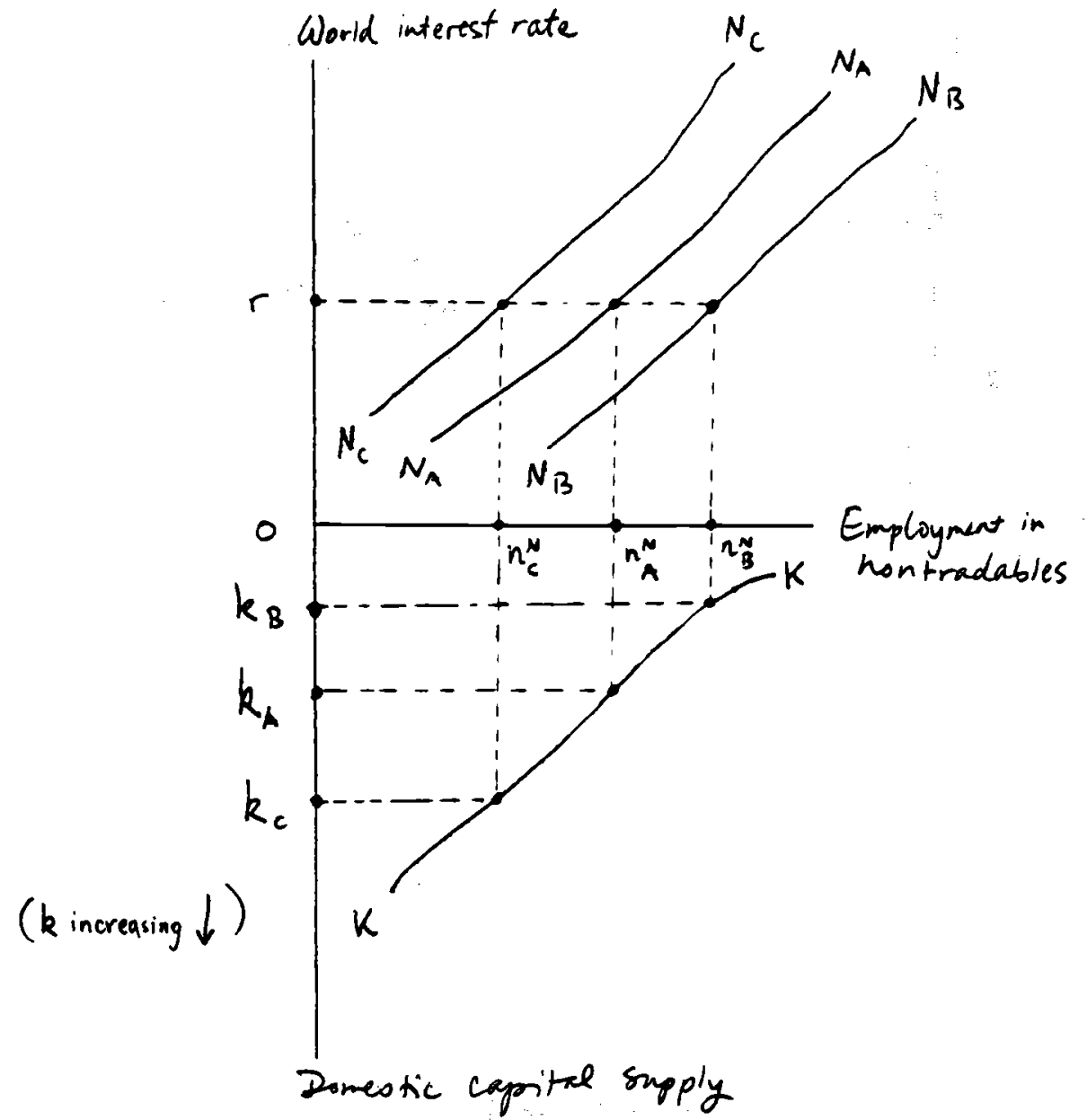

Figme 4 


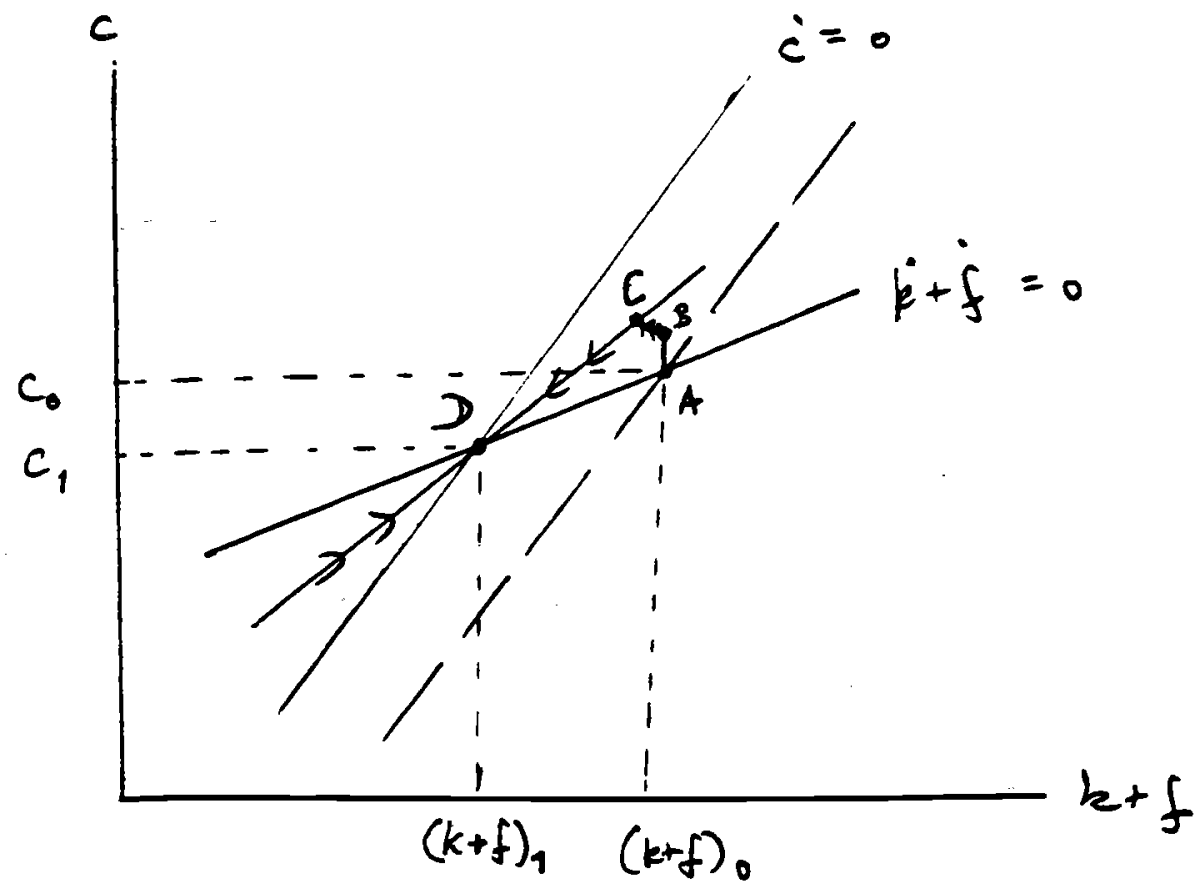

$$
\text { Figre } 5
$$


Consumption rises further until the policy is implemented (point.C), after which consumption declines to its new long-run level (point D). The details of this adjustment can be understood with the help of the arguments applied to the previous case. ${ }^{8}$

\section{B. Effects of government purchases}

The repercussions of changes in government demand depend on the relation between the domestic time preference rate and the world interest rate. Consider first a permanent, unanticipated rise in per capita government demand (measured in tradables), from $g_{0}$ to $g_{1}=g_{0}+\Delta g$. Because the spending shift is assumed not to affect the per capita public debt, it is matched by an equal rise in per capita taxes and is thus a balanced-budget policy change. For the moment, there is no need to specify whether this additional demand falls on traded or nontraded goods.

Figure 6a illustrates the economy's behavior when $r<\delta$, figure $6 \mathrm{~b}$ its behavior when $r>\delta$. In the first case, national saving rises as consumption drops from point A to point B: a rise in government spending causes an even greater drop in private spending, and the economy ends up (at point $C$ ) with a higher stock of outside assets but permanently lower private consumption. In the second case, however, the initial drop in private spending falls short of $\Delta g$, so the external surplus shrinks. Private consumption declines steadily as the economy makes its transition to a new steady state at $C$ with lower net national wealth. Only when $r$ and $\delta$ are exactly equal does government spending crowd out private spending on a one-for-one basis. When the $\dot{c}=0$ locus is vertical, the economy moves immediately to its new steady state with no fall in its long-run outside assets. ${ }^{9}$ 


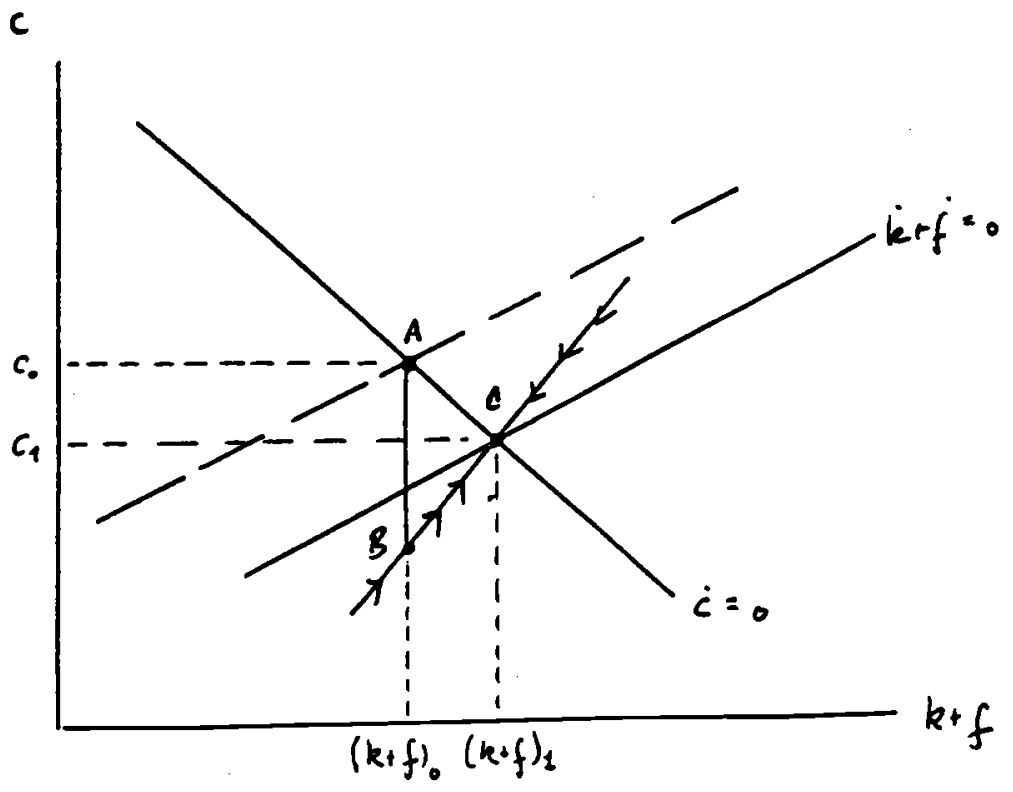

Fige 6a $(r<\delta)$

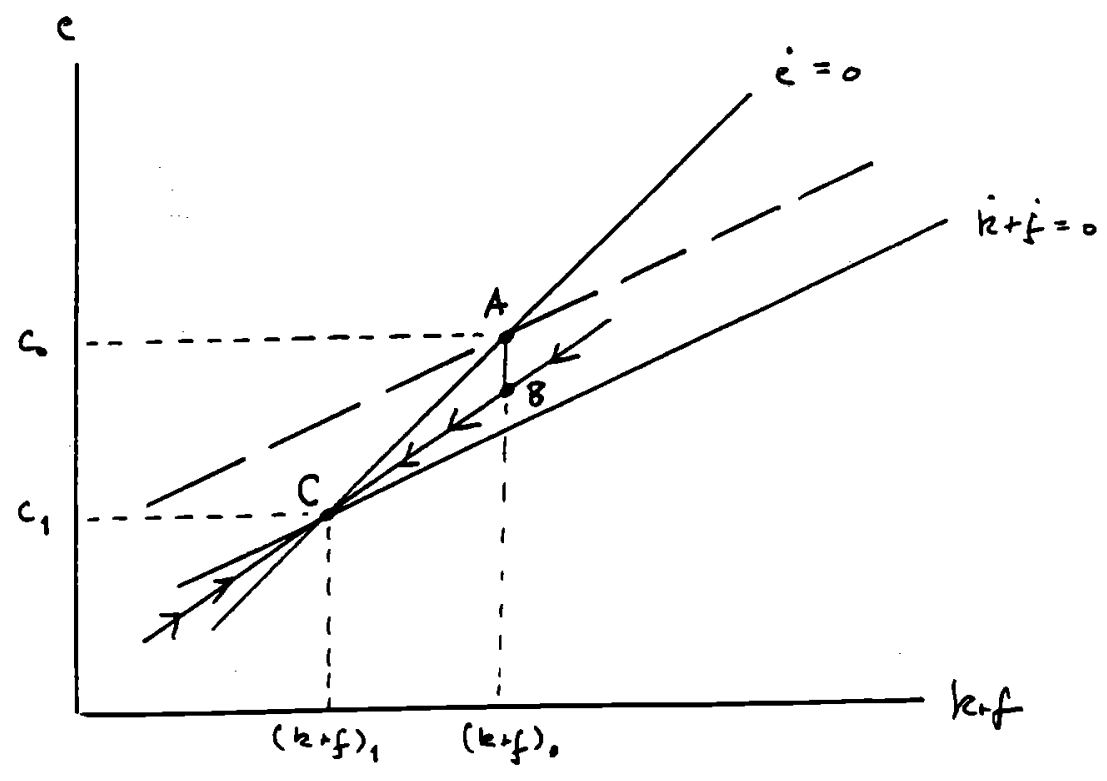

Fige 6b $\quad(r>8)$ 
The dynamics that follow even permanent public spending shifts can be understood by examining the consumption function. According to equation (20), a permanent increase $\Delta g$ in per capita government spending causes per capita consumption to change by the (negative) amount

$$
\Delta c=-[1+(\delta-r) / R r] \Delta g
$$

which is algebraically less than $-\Delta g$ if $r<\delta$ and algebraically greater than $-\Delta g$ if $\mathbf{r}>\delta$. Looked at another way, the effect of the fiscal change on saving depends on the size of the marginal propensity to consume out of wealth relative to the real interest rate in terms of tradables. The economic rationale for this result is straightforward. According to equation (15), each household's consumption is falling over time when $r<\delta$ and rising over time when $r>\delta$. In the former case, a permanent balancedbudget spending increase has a greater proportional impact on future consumption than on present consumption if private saving does not adjust. Private saving must therefore jump upward immediately to ensure that the marginal utility of private consumption rises over the future at the rate $\delta$ - r. Run in reverse, the same argument shows why private saving falls immediately when household consumption is rising over time. (The next section shows that while the case $r>\delta$ is likely to be the relevant one in a general-equilibrium context, either of the patterns just described can arise.)

When the increased government spending fails entirely on traded goods, the contraction of private consumption implies an immediate fall in nontraded-sector employment and a rise in the home capital supply. 
Qualitatively, these effects persist in the long run, so capital is again crowded in.

When incremental government spending falls on nontraded goods, the initial increase in the capital stock is reduced and is likely to be reversed. When $r<\delta$ the long run fall in private consumption is less than $\Delta \mathbf{g}$ [equation (21)], so capital is definitely crowded out in the long run and the foreign asset stock is higher. When $r>\delta$ the long-run capital stock is also likely to fall, but need not. Increased government spending on nontradables clearly leads to greater long-run crowding out of capital than increased government spending on tradables.

The case of an anticipated future increase in government spending can be analyzed as before. Figure 7 shows how consumption falls initially (from point $A$ to point $B$ ), and how outside assets rise thereafter, until the fiscal change is implemented (point $C$ ). In the case shown in the figure, private consumption starts by rising from point B but then falls as the increase in public spending -- and the accompanying rise in taxes -approaches. Point D is the economy's final position.

5. Global effects of fiscal policies

In this section, the preceding small-country analysis is extended to a global setting. The resulting model shows how fiscal policies in a large country affect the world interest rate, relative prices, industrial structures, and the world capital stock.

\section{A. A two-country world economy}

The model studied in previous sections is now modified by the addition of a second country, identical to the first in technology, population, and 


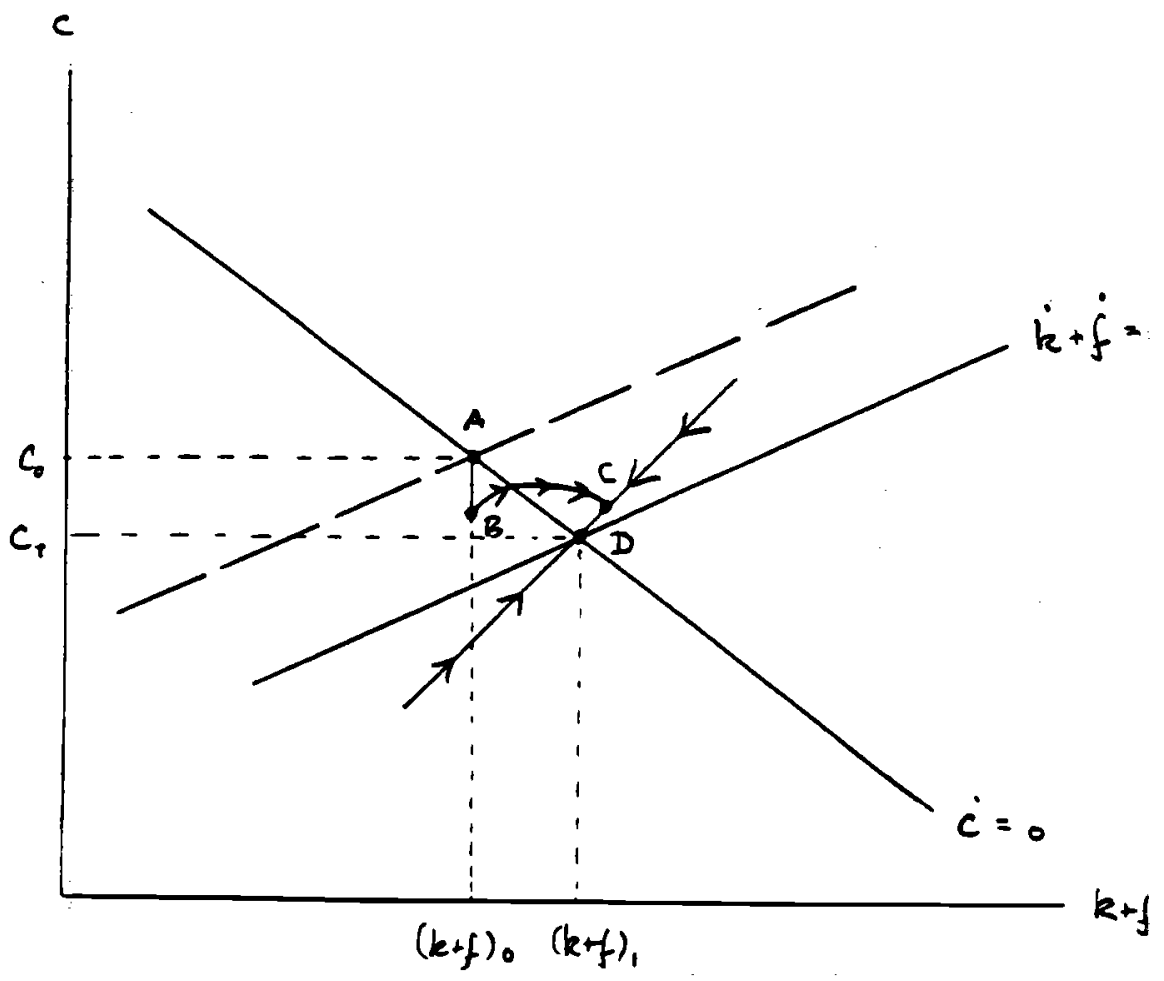

Fige 7 
in the preferences of its households. ${ }^{10}$ The world economy is assumed to consist of the two similar economies, referred to as Alpha and Beta, respectively. An additional condition determining the world interest rate closes the model.

The world interest rate is determined by the equilibrium of the world capital market. Equation (11) determines the per capita demand for capital in Alpha and an identical equation determines the per capita demand for capital in Beta. The world capital market clears when the sum of these per capita demands equals the sum of the per capita supplies, $\mathrm{k}^{\alpha}+\mathrm{k}^{\beta}$ :

$$
k^{\alpha}+k^{\beta}=\left[2-\left(n^{N \alpha}+n^{N \beta}\right)\right] x^{T}(r)+\left(n^{N \alpha}+n^{N \beta}\right) x^{N}[q(r) r] .
$$

Equation (10), however, allows the elimination of $n^{\mathrm{N \alpha}}$ and $n^{\mathrm{N} \beta}$ from the above equation, so that

$$
\begin{aligned}
& \mathrm{k}^{\alpha}+\mathrm{k}^{\beta}= \\
& 2 \mathrm{x}^{\mathrm{T}}(\mathrm{r})+\frac{\left\{\mathrm{x}^{\mathrm{N}}[\mathrm{q}(\mathrm{r}) \mathrm{r}]-\mathrm{x}^{\mathrm{T}}(\mathrm{r})\right\}}{\mathrm{F}^{\mathrm{N}}\left(\mathrm{x}^{\mathrm{N}}[\mathrm{q}(\mathrm{r}) \mathrm{r}], 1\right\}}\left[(1-\nu) \mathrm{q}(\mathrm{r})\left(\mathrm{c}^{\alpha}+\mathrm{c}^{\beta}\right)+\mathrm{g}^{\mathrm{N} \alpha}+\mathrm{g}^{\mathrm{N} \beta}\right] .
\end{aligned}
$$

The market-clearing condition (23) shows that the equilibrium world interest rate can be written as a function of the capital and consumption aggregates, $k^{\alpha}+k^{\beta}$ and $c^{\alpha}+c^{\beta}$, and of the overall government demand for nontradables, $\mathrm{g}^{\mathrm{N} \alpha}+\mathrm{g}^{\mathrm{N} \beta}:{ }^{11}$

$$
r=r\left(c^{\alpha}+c^{\beta}, k^{\alpha}+k^{\beta}, g^{\mathrm{N} \alpha}+g^{N \beta}\right)
$$


Government purchases of traded goods do not appear in equation (24) because, given private consumption, changes in such purchases can be accommodated through equal opposite changes in the rate of capital accumulation, with no instantaneous effect on factor markets. The form of (24) is thus entirely dependent on the assumption that only traded goods can be transformed into capital.

The appendix reports the partial derivatives of the world interest rate function (24), but its properties can be understood intuitively.

An increase in world consumption. By increasing world demand for labor-intensive nontradables, a rise in consumption leads to an excess supply of capital relative to labor at a given interest rate. A fall in the interest rate restores equilibrium by raising the relative price of nontradables, thereby lowering demand for them, and by encouraging both sectors to adopt labor-saving production techniques. The rise in consumption naturally raises demand for traded as well as nontraded goods, but, once again, the additional demand for tradables can be satisfied out of a fall in world capital accumulation.

An increase in world capital. A rise in the world ratio of capital to labor occasions an initial excess supply of capital. A fall in the world interest rate, however, induces both the tradable and nontradable sectors to adopt more capital-intensive techniques. Because q declines when $r$ declines, demand shifts away from the labor-intensive nontradables sector. This shift reinforces the equilibration process by reducing the excess supply of capital relative to labor.

An increase in government demand for nontradables. Again, this disturbance causes the world interest rate and the relative price of tradables to fall. 
Define $k^{*} \equiv k^{\alpha}+k^{\beta}, c * \equiv c^{\alpha}+c^{\beta}, g^{N *}=g^{N \alpha}+g^{N \beta}$. Then the preceding discussion is summarized by the following partial derivatives:

$$
r_{c \star}<0, r_{k \star}<0, r_{g N *}<0 .
$$

B. Aggregate dynamics

Since $f^{\alpha}=-f^{\beta}$, equations (17) and (18), which apply to both Alpha and Beta, can be combined to yield laws of motion for world consumption, $c *$, and world capital, $k *$. The analysis is now restricted to the case of logarithmic consumers $(R=1)$, so that the resulting equations are:

$$
\dot{k}^{*}=\left[r\left(c^{*}, k^{*}, g^{N *}\right)-\mu\right] k^{*}+2 w\left[r\left(c^{*}, k^{*}, g^{N *}\right)\right]-c^{*}-g^{*},
$$

where $\mathrm{d} * \equiv \mathrm{d}^{\alpha}+\mathrm{d}^{\beta}$ and $\mathrm{g}^{\star} \equiv \mathrm{g}^{\alpha}+\mathrm{g}^{\beta} \cdot 12$

The matrix of partial derivatives of this system is

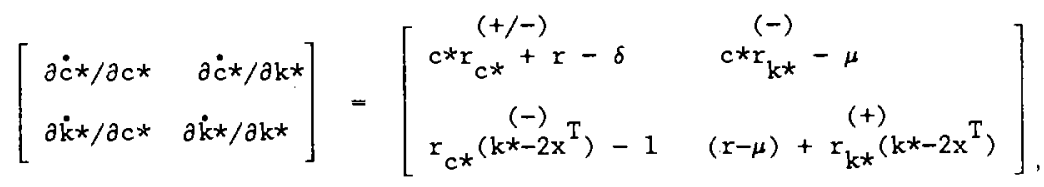

the same sign pattern as in the small-country case. ${ }^{13}$ The assumption that the matrix above has one positive and one negative root is insufficient to ensure local saddlepath stability for the world economy: the disaggregated underlying system consists of four differential equations involving two predetermined variables. The roots of the linearized four-equation system 
capital can rise or fall in the long run. Reinforcing the direct negative effect of higher taxes on consumption is the negative effect of the world interest rate. The interest rate rises when the policy is implemented, an it also rises in the long run. The rise in the steady-state interest rate is obvious in figure $11 \mathrm{~b}$, where $c *$ and $k *$ both fall in the long run [recal (25)]. In figure 1la, however, world consumption would be declining at $c$ if the move from $A$ to $C$ left the interest rate constant isee equation (26)]. So the long-run interest rate must rise in the case illustrated there, as well. Notice, though, that in figure 11 a the interest rate "overshoots" its eventual level in the short run.

This interest-rate behavior has implications for the international transmission of expenditure shocks. In the short run private consumption falls in both countries (recall the assumption that human wealth is positive). In the likely case that world capital is eventually crowded out, Alpha's outside assets fall in the long run; its private consumption, measured in tradables, always falls. (Symmetric initial fiscal positions are still assumed.) As before, Beta's private consumption and outside assets can rise or fall in the long run.

Because long-run consumption and outside assets fall by relatively less in Beta, that country has a relatively smaller share of the world's capital in the final equilibrium and thus a larger stock of claims on Alpha. The latter country's external debt ultimately must increase. The analysis of an increase in public consumption of nontradables is somewhat more complicated because the latter variable has a direct effect on the world interest rate. In particular, the $\dot{c} *=0$ locus now shifts along with the $\dot{k} *=0$ locus. Figures $12 \mathrm{a}$ and $12 \mathrm{~b}$ show possible adjustment processes. A useful way to think of this disturbance is as a combination 


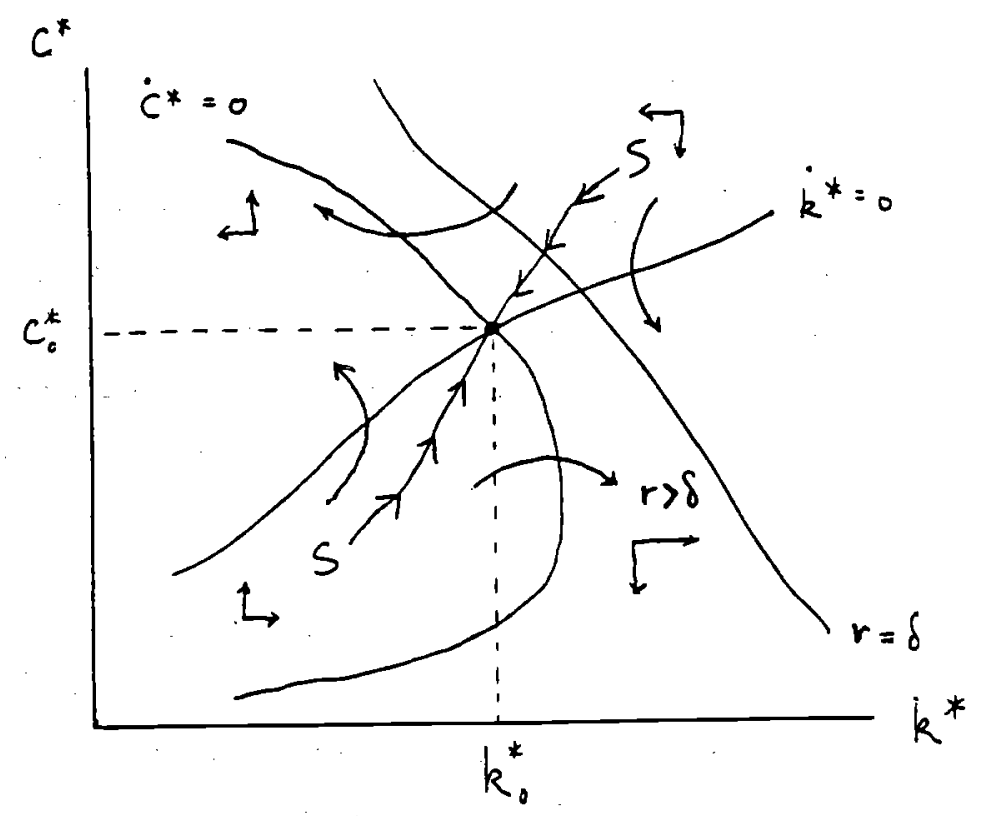

Figne $8 a$

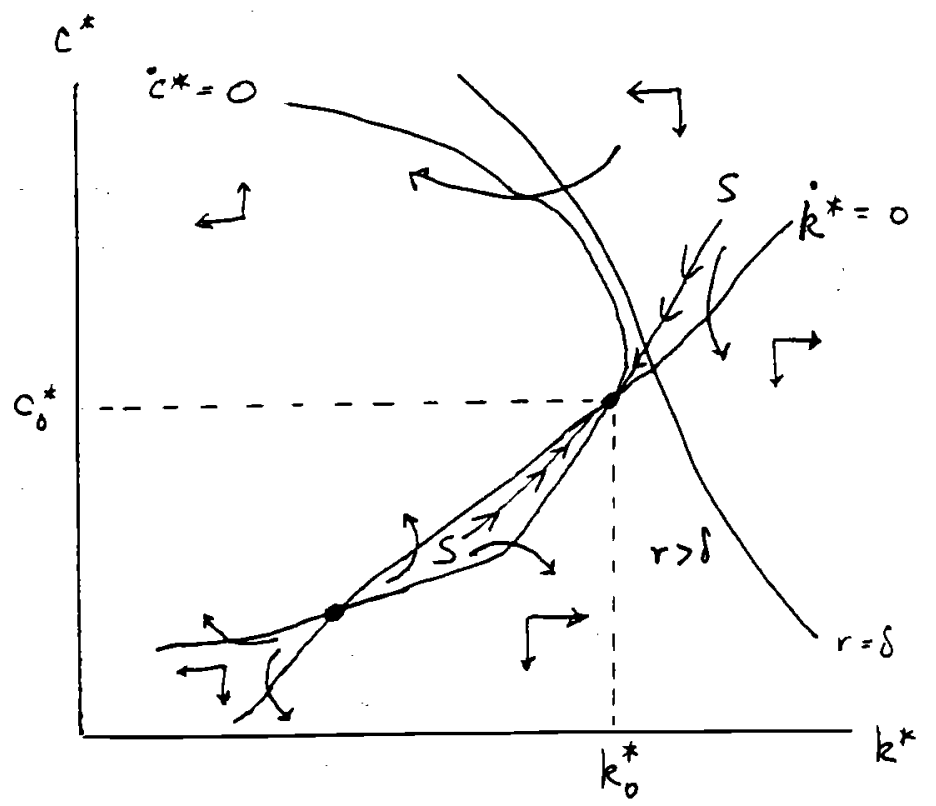

Figne 8b 
considered are small enough that a saddlepath equilibrium still exists after they occur.

In interpreting the model, it is important to remember that the dynamics portrayed do not fully capture the underlying evolution of asset stocks in Alpha and Beta. Imagine, for example, that the world economy is at its steady state and that both Alpha and Beta are individually in steady states with constant ratios of external assets to population. A transfer of external assets from Alpha to Beta will lead to an increased current account deficit for Beta and an increased surplus for Alpha; but average world consumption will not change and the world interest rate will not change. Each country will adjust as in the small-country case - that is, at a constant interest rate -. until both simultaneously regain external balance. The world-average dynamics shown in figures $8 \mathrm{a}$ and $8 \mathrm{~b}$ mask the possibility that adjustment of this sort is going on at the country level.

\section{Changes in public debt}

A rise in either country's long-run debt ratio raises the corresponding world magnitude, $d *$, and thus shifts the $\dot{c} *-0$ schedule to the left. Figure 9 shows how this change affects the world economy. Average world consumption rises initially (from point $A$ to $B$ ) and world investment falls. In the new steady state (point $C$ ), however, the world capital stock is smaller relative to the labor force than at the original steady state, and average world consumption is correspondingly lower. Debt expansion anywhere crowds out capital on a global scale.

An interesting aspect of the adjustment process is that the world interest rate falls when consumption initially rises. This fall preserves capital-market equilibrium in the face of a worldwide increase in the 


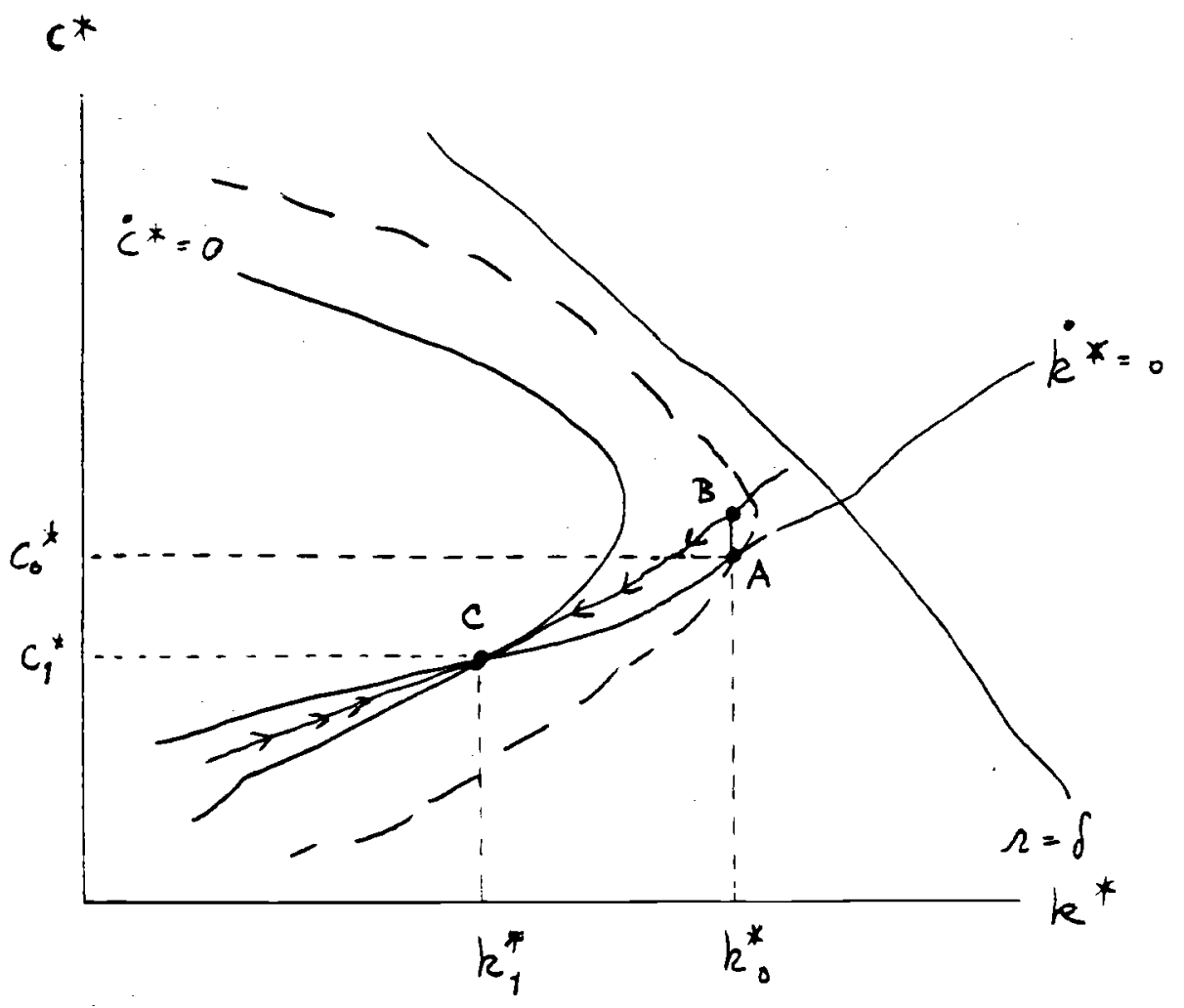

Figne 9 
demand for labor-intensive nontradables. Of course, the relative price of nontradables also rises initially in both countries. In the long run, however, the interest rate ends up above its original level (since both c* and $k *$ are lower) and the relative price of nontradables therefore is below its original level.

Together with the information that the long-run world interest rate rises, equations (21) and (22) (for the present case $R-1$ ) can be used to deduce the long-run effects of the public debt shock on Alpha and Beta individually. (This use relies on a saddlepath condition, $-\mu+\mathbf{r}-\delta<0$. ) Assume that the shock originates in Alpha, and that fiscal parameters are initially the same in the two countries. Equation (21) then implies that steady-state consumption falls by more in Alpha than in Beta, so that $c^{\alpha}$ must fall in the long run (while $c^{\beta}$ may fall or rise). 15

Equation (22), by a similar argument, implies that the steady-state value of $(k+f)^{\alpha}$ must fall; $(k+f)^{\beta}$ falls by less, may rise in the long run, and must rise if $c^{\beta}$ rises. Since $c^{\beta}$ rises relative to $c^{\alpha}$, consumption of nontradables in Beta rises relative to such consumption in Alpha, leading to a long-run decline in $k^{\beta}$ relative to $k^{\alpha}$. $k^{\beta}$ therefore falls absolutely as well, and $\mathrm{f}^{\beta}$ must rise, implying an equal fall in $\mathrm{f}^{\alpha}$. If $\mathrm{f}^{\beta}$ did not rise, Alpha's outside assets would have to rise relative to Beta's, a contradiction.

D. Long-run welfare analysis of changes in public debt

Figures $10 \mathrm{a}$ and $10 \mathrm{~b}$ illustrate the steady-state welfare implications of a higher domestic public debt ratio for an average Alpha consumer. Both figures assume that Alpha's net foreign claims are initially zero. Each production possibilities curve shows how different efficient allocations of 


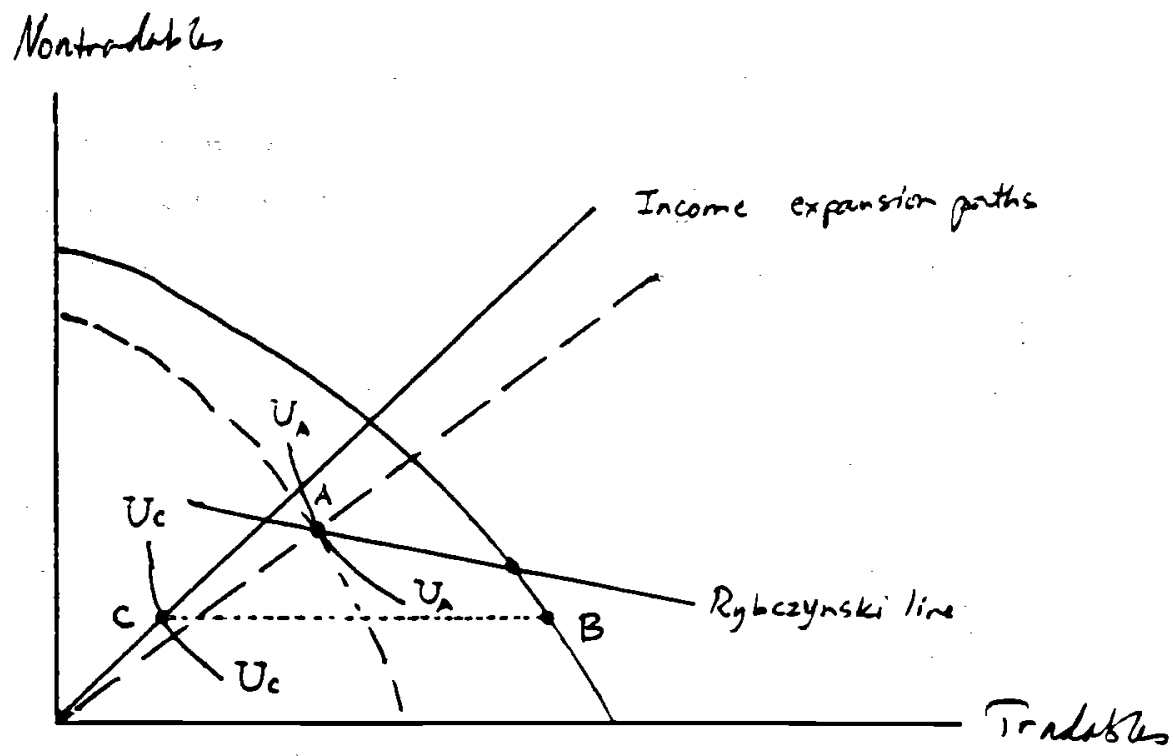

Figne 10a $\left(k^{\alpha}\right.$ rises $)$

Nontradables

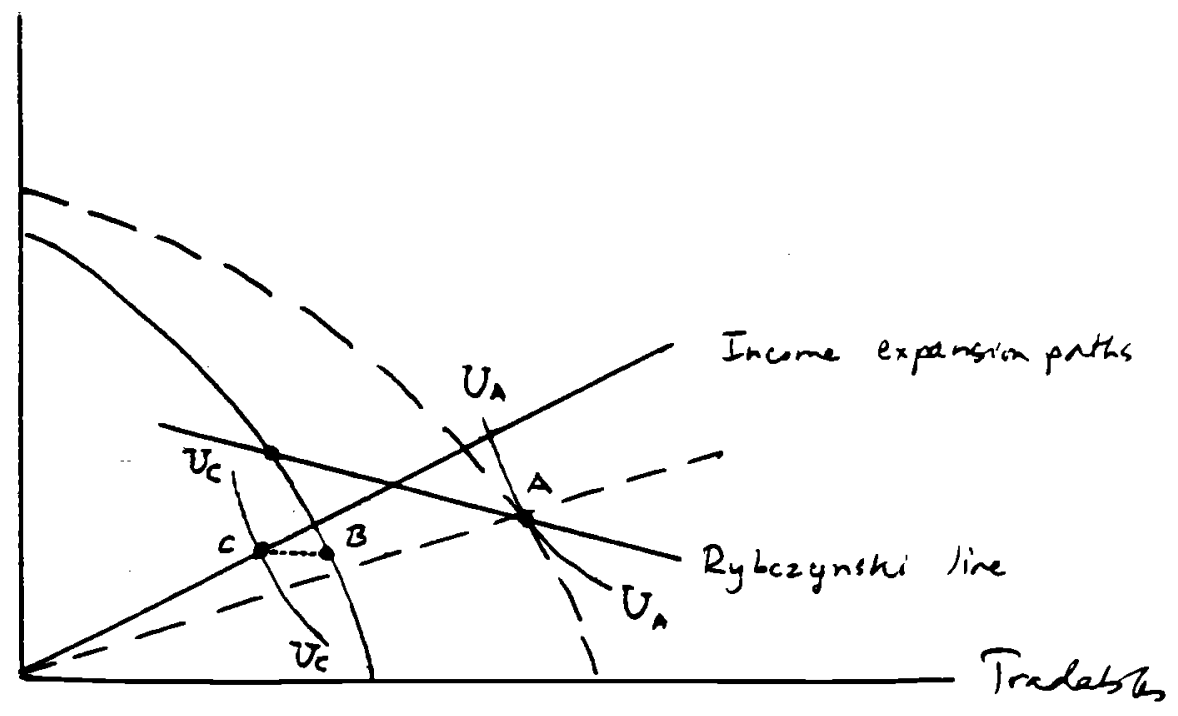

Figre $10 b$ ( $k^{\alpha}$ fall $)$ 
labor and a given capital stock alter per capita output of nontradables ani per capita output of tradables less the investment per worker needed to maintain a fixed economy-wide capital-labor ratio.

Figure 10a depicts the case in which Alpha's long-run capital stock per worker is higher after the disturbance. In the absence of an increase in the world price of tradables in terms of nontradables, production would move from point $A$, downward along the Rybczynski line, to the outer production possibilities curve. Since tradables are more expensive in the long run, however, actual production is at $B$ and the economy's income expansion path is steeper than the initial, broken path. Long-run equilibrium is at $C$, where the nontradables market clears. Welfare, shown by the indifference curve $\mathrm{U}_{\mathrm{C}} \mathrm{U}_{\mathrm{C}}$, is below its original level, indicated by $\mathrm{U}_{\mathrm{A}} \mathrm{U}_{\mathrm{A}}$. An income transfer from future to present generations is implied. A similar long-run welfare loss occurs in the case shown in figure 10b, in which Alpha's long-run capital-labor ratio falls. Now, production shifts from $A$ to $B$ and consumption from A to $C$. Notice that consumption point $C$ must always lie to the left of production point $B$ because Alpha ha: become a net debtor to Beta and $r>\mu$.

\section{E. Changes in government purchases}

The distinction between government purchases of traded and nontraded goods raises takes on additional importance in a global context. Figures Ila and IIb show the effects of a permanent balanced-budget increase in public consumption of tradables for two alternative configurations of long: run equilibrium.

As in the small-country case, private consumption can fall on impact by more or by less than the increase in government consumption, so world 


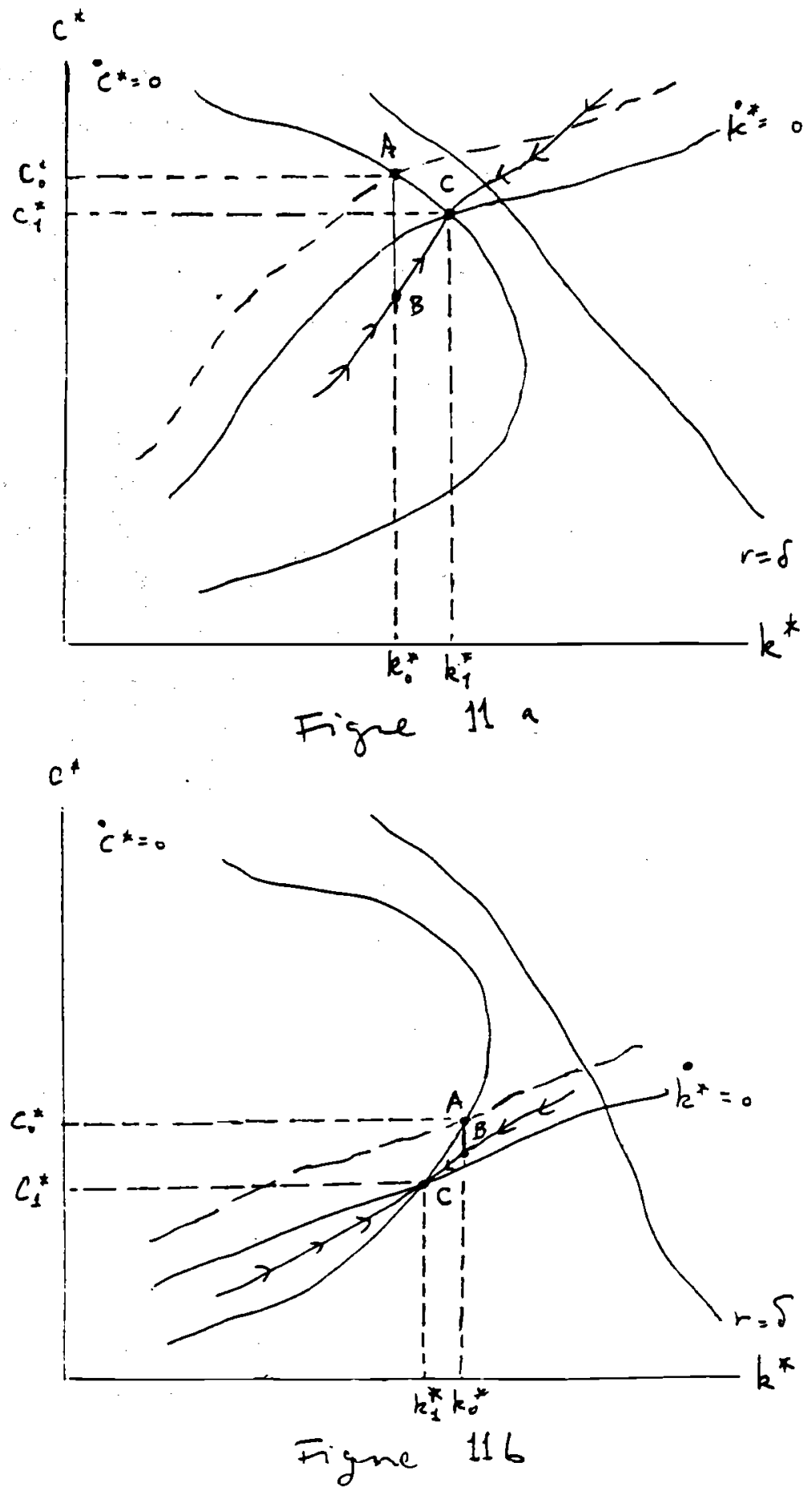


capital can rise or fall in the long run. Reinforcing the direct negative effect of higher taxes on consumption is the negative effect of the world interest rate. The interest rate rises when the policy is implemented, an it also rises in the long run. The rise in the steady-state interest rate is obvious in figure $11 \mathrm{~b}$, where $c *$ and $k *$ both fall in the long run [recal (25)]. In figure 1la, however, world consumption would be declining at $c$ if the move from $A$ to $C$ left the interest rate constant isee equation (26)]. So the long-run interest rate must rise in the case illustrated there, as well. Notice, though, that in figure 11 a the interest rate "overshoots" its eventual level in the short run.

This interest-rate behavior has implications for the international transmission of expenditure shocks. In the short run private consumption falls in both countries (recall the assumption that human wealth is positive). In the likely case that world capital is eventually crowded out, Alpha's outside assets fall in the long run; its private consumption, measured in tradables, always falls. (Symmetric initial fiscal positions are still assumed.) As before, Beta's private consumption and outside assets can rise or fall in the long run.

Because long-run consumption and outside assets fall by relatively less in Beta, that country has a relatively smaller share of the world's capital in the final equilibrium and thus a larger stock of claims on Alpha. The latter country's external debt ultimately must increase. The analysis of an increase in public consumption of nontradables is somewhat more complicated because the latter variable has a direct effect on the world interest rate. In particular, the $\dot{c} *=0$ locus now shifts along with the $\dot{k} *=0$ locus. Figures $12 \mathrm{a}$ and $12 \mathrm{~b}$ show possible adjustment processes. A useful way to think of this disturbance is as a combination 


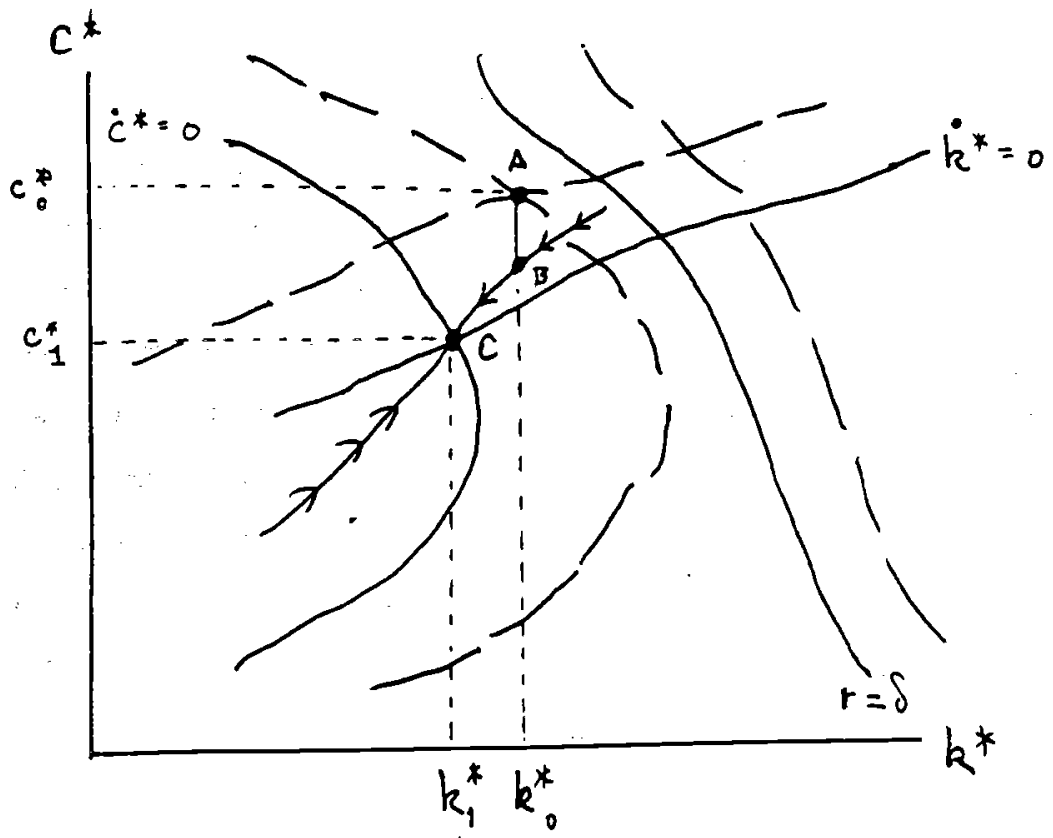

Figne 12 a

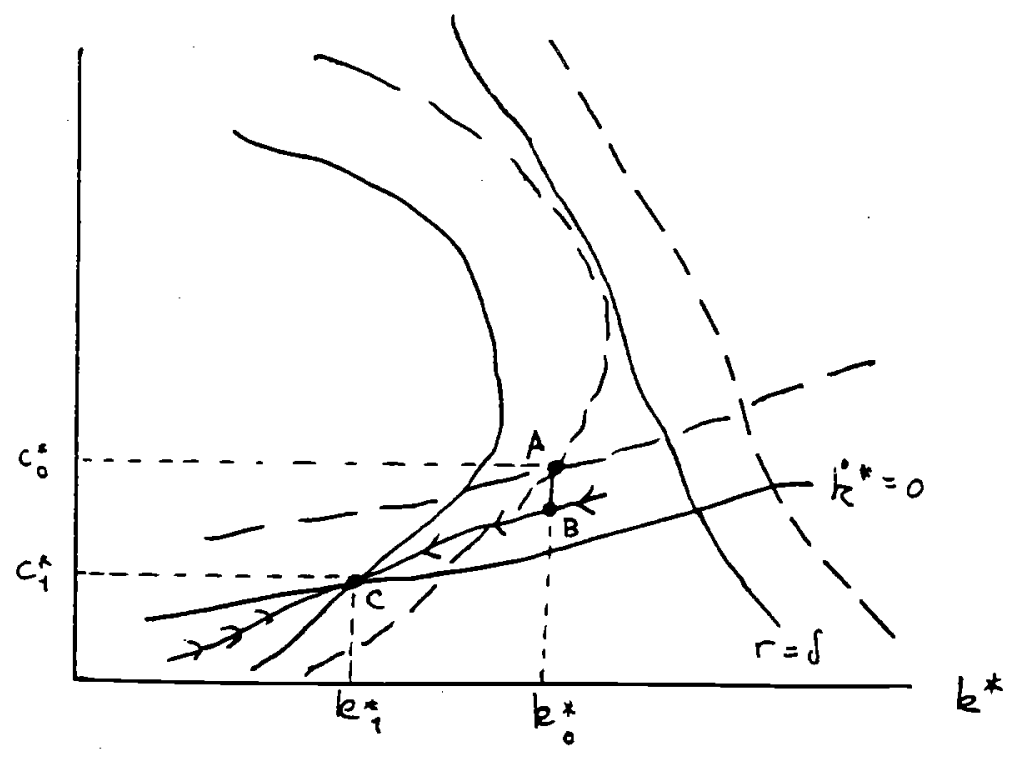

Figne 126 
of (i) a rise in government demand for nontradables coupled with a private demand shift away from nontradables such that the two changes together leave the interest rate (and q) the same for all $c^{*}$ and $k *$ plus (ii) a reversal of the private demand shift. Change (i) is roughly equivalent (for small changes) to a rise in government purchases of tradables equal in value (at the initial relative price) to the rise in purchases of nontradables. Direct calculation shows that change (ii) alone is 1ikely to depress $c^{*}$ and $k^{*}$ in the long run. In this sense, an increase in $g^{N *}$.. (i) plus (ii) - is likely to have a greater crowding-out effect than an equivalent increase in $\mathrm{g}^{\mathrm{T}^{*}}$.. that is, (i) alone.

\section{Conclusion}

A model of growing world economy peopled by infinitely-lived households that are not altruistically linked yields some sharp predictions about how national debt and public spending policies affect global consumption/production patterns and capital intensity. The results hinge strongly on the two-sector production structure assumed and on some additional simplifying assumptions.

Perhaps the most unrealistic of these assumptions is that capital can be instantaneously shifted between sectors within a country and, indeed, between countries. The introduction of temporary sector-specificity of productive factors would alter the model's short-run behavior considerably and would probably necessitate numerical solution procedures. Most longerrun predictions of the model would, however, remain qualitatively unchanged, which is why the model is best viewed as describing medium- to long-term adjustment. It would also be desirable to allow increased real exchange rate variation by relaxing the assumption that all tradables, 
wherever produced, are perfect substitutes in consumption. This extension, like the introduction of factor-movement frictions, may be most relevant to the model's short-run behavior. 16

Also crucial to the simplicity of the model's solution was the assumption of two absolutely identical countries. Such strict symmetry, while consistent with the Heckscher-Oh1in-Samue1son tradition in international trade theory, prevents the analysis of at least some issues related to the transfer problem. Another realistic modification would allow new capital to be produced from existing capital and labor according to a neoclassical production function [see, for example, Samuelson (1965)]. This change would allow for a more complicated interplay among relative factor intensities, aggregate demand fluctuations, and investment.

There are at least three other directions in which the present work could be extended. First, a more detailed welfare analysis of fiscal policies, perhaps along the lines sketched by Calvo and Obstfeld (1988), could be a useful component of a normative theory of international fiscal policy coordination. Romer (1988) has carried out such an analysis for a small economy, and his results indicate that the welfare effects of fiscal deficits can be significant even when deviations from Ricardian equivalence are small (as is possibly true above). Second, the model could be applied to simulate the long-run global effects of growing per capita public-debt levels, as in Tobin (1986). Such simulations would be relevant in evaluating the economic implications of a political process that fails to stabilize the ratio of debt to national income. A third extension, following Frenkel and Razin (1986b), would explore the effects of alternative budgetary policies when taxation is distortionary. 


\section{Footnotes}

1. For related models, generally of small economies, see Engel and Kletzer (1987), Guldotti (1987), Neary and Purvis (1983), and Razin (1984).

2. International evidence generally supports the assumption that nontraded goods, taken as an aggregate, are labor intensive relative to tradables. See, for example, Kravis and Lipsey (1983).

3. To derive this equation, integrate by parts and invoke the condition $\lim _{s \rightarrow} \exp [-r(s-t)] d(s)=0$, which follows from (13).

4. Given dynamic efficiency $(r>\mu)$, the inequality $-\mu+(r-\delta) / R<0$ implies another inequality that was assumed earlier, $\Omega=r+(\delta-r) / R>0$. To see the link between the first inequality and the signs of aggregate consumption and human wealth, observe that in a steady state, (17) implies that

$$
h(t) / c(t)=\left(\mu+\frac{\delta-r}{R}\right) / \mu \Omega>0 .
$$

5. For further discussion, see Well (1985), Abel (1987), and Buiter (1988). A two-country version of Blanchard's (1985) model would give results similar to those found below. Well's framework seems preferable, however, for two reasons. First, it is simpler, in that is dispenses with the analytically inessential assumption that death occurs. Second, it allows discussion of some growth-related questions.

6. Notice that Feldstein's (1976) financing scheme is consistent with intertemporal budget balance even in a static economy: his suggestion makes no essential use of the fact of real economic growth, and requires only that the per capita public debt grow over time at a rate below the interest rate. For a formal demonstration that this growth pattern of the debt is consistent with public solvency, see McCallum (1984).

7. Recall that $-\mu+(r-\delta) / R$ and $(1-R) r-\delta$ must be negative (as discussed in footnote 4).

8. When $r<\delta$ (as in figure 2a), consumption falls after its initial upward jump.

9. For similar results with $R=1$, see Puumanen (1986, pp. 63-64).

10. Aoki (1981) has stressed the usefulness of such symmetry assumptions in analyzing dynamic multi-country models.

11. To be exact, each of these aggregates equals twice the world per capita level. 
12. Notice that the market for tradables always clears as a result of Walras's law. Because the nontradables markets in Alpha and Beta clear [equation (10)], constraint (27) implies equilibrium in the world tradables market.

13. Only the assertion that the southwest entry is negative requires some justification. To see why $\partial \mathrm{k}^{*} / \partial c^{*}<0$, start by taking the expressions in the appendix for the Leontief case $\left(x^{T}=x^{N}=0\right)$, use the equation displayed just above (23) to eliminate $k \star$, and invoke a standard result of the two-sector model, that $(r / q)(d q / d r)=r\left(x^{T}-x^{N}\right) /\left(r x^{N}+w\right)$. Now notice that variability of the production technique only reduces $\partial k^{*} / \partial c^{*}$, because world production can shift away from tradables when $r$ and q fall on account of a rise in $c^{*}$. Strictly speaking, the argument just given requires that $\mathrm{g}^{\mathrm{N}^{\star}}=0$. This is an artifact of the (somewhat unsatisfactory) way equation (27) is specified. With $g^{N^{*}}$ and $g^{*}$ both given and nonzero, the fall in q caused by a rise in c* automatically implies a fall in $\mathrm{g}^{\mathrm{T}}$; thus, world investment could, conceivably, rise. This possibility is empirically remote enough that it can safely be ignored.

14. The proof proceeds by writing out the linear approximation to the four-equation system and using elementary row and column operations to simplify the associated determinant, which is the product of the system's characteristic roots.

15. Notice that, $r(\mu+\delta-r)$ is decreasing in $r$ (because $r>\mu$ and $r>\delta$ at the initial equilibrium).

16. See Obstfeld (1988) for a sketch of a model incorporating a variable real exchange rate. 
33

Appendix: Partial derivatives of $r\left(c *, k *, g^{N *}\right)$

Equation (23) giving the equilibrium interest rate $r$ can be written as $\phi\left(r, c^{\star}, g^{N \star}\right)-k \star-0$. Then if $n^{N \star}=n^{N \alpha}+n^{N \beta}$,

$$
\begin{aligned}
& \phi_{r}=\left(2-n^{N \star}\right) x^{T}-\left(x^{T}-x^{N}\right)(1-\nu)\left[c q^{\prime} / F^{N}\left(x^{N}, 1\right)\right] \\
& +n^{N \star}\left(r q^{\prime}+q\right) x^{N},\left[1+\left(x^{T}-x^{N}\right) r q / F^{N}\left(x^{N}, 1\right)\right]<0, \\
& \phi_{c \star^{*}}-(1-\nu)\left(x^{T}-x^{N}\right) / F^{N}\left(x^{N}, 1\right)<0, \\
& \phi_{g N *}=-\left(x^{T}-x^{N}\right) / F^{N}\left(x^{N}, 1\right)<0 .
\end{aligned}
$$

Thus, $r_{c^{\star}}=-\phi_{c^{\star}} / \phi_{r}<0 ; r_{k^{\star}}-1 / \phi_{r}<0 ;$ and $r_{g^{\star}}=-\phi_{g N^{*}} / \phi_{r}<0$. 


\section{References}

Abel, Andrew B., 1987, Birth, death, and taxes, mimeo, Wharton School, University of Pennsylvania.

Abe1, Andrew B, at al. 1986, Assessing dynamic efficiency: Theory and evidence, mimeo, Wharton School, University of Pennsylvania.

Aoki, Masanao, 1981, Dynamic analysis of open economies. New York: Academic Press.

Barro, Robert J., 1974, Are government bonds net wealth?, Journal of Political Economy 82, $1095-1117$.

, 1976, Reply to Feldstein and Buchanan, Journal of Political Economy $84,343-349$.

Blanchard, Olivier J., 1985, Debt, deficits, and finite horizons, Journal of Political Economy 93, 223-247.

Buiter, Willem H., 1981, Time preference and international lending and borrowing in an overlapping-generations model, Journal of Political Economy $89,769-797$.

1986, Fiscal policy in open, interdependent economies, in: Economic policy in theory and practice, Assaf Razin and Efraim Sadka, eds. London: Macmillan.

, 1988, Death, birth, productivity growth and debt neutrality, Economic Journal 98, 279-293.

Calvo, Guillermo A. and Maurice Obstfeld, 1988, Optimal time-consistent fiscal policy with finite lifetimes, Econometrica 56, 411-432.

Diamond, Peter A., 1965, National debt in a neoclassical growth model, American Economic Review 55, 1126-1150.

Engel, Charles and Kenneth Kletzer, 1987, Saving and investment in an open economy with non-traded goods, mimeo, University of Virginia.

Feldstein, Martin S., 1976, Perceived wealth in bonds and social security: A comment, Journal of Political Economy 84, 331-336.

Frenke1, Jacob A. and Assaf Razin, 1986a, The international transmission and effects of fiscal policies, American Economic Review Papers and Proceedings 76, 330-335.

Frenkel, Jacob A, and Assaf Razin, 1986b, Deficits with distortionary taxes: International dimensions, NBER Working Paper no. 2080.

Fried, Joel and Peter Howitt, 1988, Fiscal deficits, international trade and welfare, Journal of International Economics 24, 1-22. 
Giovannini, Alberto, 1988, The real exchange rate, the capital stock, and fiscal policy, European Economic Review, forthcoming.

Greenwood, Jeremy and Kent P. Kimbrough, 1985, Capital controls and fiscal policy in the world economy, Canadian Journal of Economics 18, 743765 .

Guidott1, Pablo, E. 1987, Optimal adjustment to international debt service requirements, mimeo, University of Colorado, Boulder.

Koopmans, Tjalling C., 1967, Intertemporal distribution and 'optimal' aggregate economic growth, in: Ten economic studies in the tradition of Irving Fisher. New York: John Wiley \& Sons.

Kravis, Irving B. and Robert E. Lipsey, 1983, Toward an explanation of national price levels, Princeton Studies in International Finance no. 52 , November.

McCallum, Bennett T., 1984, Are bond-financed deficits inflationary? A Ricardian analysis, Journal of Political Economy 92, 123-135.

Mundell, Robert A., 1957, International trade and factor mobility, American Economic Review 47, 321-335.

Neary, J. Peter and Douglas D. Purvis, 1983, Real adfustment and exchange rate dynamics, in: Exchange Rates and international macroeconomics, Jacob A. Frenkel, ed. Chicago: University of Chicago Press.

Obstfeld, Maurice, 1985, The capital inflows problem revisited: A stylized model of Southern Cone disinflation, Review of Economic Studies 52 , 605-625.

1988, Comment (on William H. Branson, Sources of misalignment in the 1980s), in: Misalignment of exchange rates: Effects on trade and industry, Richard C. Marston, ed. Chicago: University of Chicago Press.

Persson, Torsten, 1985, Deficits and intergenerational welfare in open economies, Journal of International Economics 19, 67-84.

Puumanen, Kari, 1986, Three essays on money, wealth and the exchange rate Helsinki: Bank of Finland.

Razin, Assaf, 1984 Capital movements, intersectoral resource shifts and the trade balance, European Economic Review 26, 135-152.

Romer, David H., 1988, What are the costs of excessive deficits?, in: NBER Macroeconomics Annual 3, Stanley Fischer, ed. Cambridge, MA: MIT Press.

Samuelson, Paul A., 1965, Equalization by trade of the interest rate along with the real wage, in: Trade, growth and the balance of payments: Essays in honor of Gottfried Harberler. Chicago: Rand McNally \& Company. 
Tobin, James, 1986, The monetary-fiscal mix: Long-run implications, American Economic Review Papers and Proceedings 76, 213-218.

Weil, Philippe, 1985, Overlapping families of infinitely-lived.agents, mimeo, Harvard University. 